\title{
Role of TLR-4 in Liver Macrophage and Endothelial Cell Responsiveness During Acute Endotoxemia
}

\author{
Li C. Chen ${ }^{1}$, Ronald E. Gordon ${ }^{3}$, Jeffrey D. Laskin ${ }^{2}$, and Debra L. Laskin ${ }^{1}$ \\ ${ }^{1}$ Rutgers University, Piscataway, New Jersey 08854 \\ ${ }^{2}$ University of Medicine and Dentistry of New Jersey-Robert Wood Johnson Medical School, Piscataway, \\ New Jersey 08854 \\ ${ }^{3}$ Mount Sinai School of Medicine, New York, New York, 10029
}

\begin{abstract}
Liver macrophages and endothelial cells have been implicated in hepatotoxicity induced by endotoxin (ETX). In these studies, we analyzed the role of toll-like receptor 4 (TLR-4) in the response of these cells to acute endotoxemia. Treatment of control C3H/OuJ mice with ETX ( $3 \mathrm{mg} / \mathrm{kg}$, i.p.) resulted in increased numbers of activated macrophages in the liver. This was associated with morphological changes in the cells and a rapid (within $3 \mathrm{hr}$ ) induction of nitric oxide synthase-2, cyclooxygenase-2, microsomal PGE synthase-1, interleukin-1 beta and tumor necrosis factor alpha gene expression. In endothelial cells, acute endotoxemia led to increased expression of these genes, as well as 5-lipoxygenase. In contrast, liver sinusoidal cells from C3H/HeJ TLR-4 mutant mice were relatively unresponsive to ETX. Treatment of $\mathrm{C} 3 \mathrm{H} / \mathrm{OuJ}$, but not $\mathrm{C} 3 \mathrm{H} / \mathrm{HeJ}$ mice with ETX, resulted in activation of transcription factors AP- 1 and NF- $\mathrm{kB}$ in liver sinusoidal cells, which was evident within $3 \mathrm{hr}$. Whereas in macrophages, transcription factor activation was transient, in endothelial cells, it persisted for $24 \mathrm{hr}$. In C3H/OuJ mice treated with ETX, activation of p38 MAP kinase was also evident in macrophages and endothelial cells, and JNK kinase in macrophages. In contrast, reduced protein kinase B (AKT) was noted in macrophages. In C3H/HeJ mice, ETX administration also led to activation of p38 MAP kinase in macrophages with no effects on JNK, p44/42 MAP kinase or AKT. These studies demonstrate that liver macrophages and endothelial cells are highly responsive to acute endotoxemia. Moreover, this activity is largely dependent on TLR-4.
\end{abstract}

\section{Keywords}

inflammatory mediators; eicosanoids; MAP kinases; leukotrienes; prostaglandins

\section{Introduction}

Lipopolysaccharide (LPS) is a constituent of the cell wall of gram-negative bacteria (Raetz and Whitfield, 2002). It is a complex glycolipid composed of a hydrophilic polysaccharide portion and a toxic hydrophobic domain known as lipid A or endotoxin (ETX). The liver is continuously exposed to ETX via the portal circulation. Liver sinusoidal cells in particular,

\footnotetext{
Address correspondence to: Debra Laskin, Ph.D., Rutgers University, Department of Pharmacology and Toxicology, 60 Frelinghuysen Road, Piscataway, NJ 08854, Tel: 732-445-5862, Fax: 732-445-2534, E-mail: E-mail: laskin@ eohsi.rutgers.edu.

Publisher's Disclaimer: This is a PDF file of an unedited manuscript that has been accepted for publication. As a service to our customers we are providing this early version of the manuscript. The manuscript will undergo copyediting, typesetting, and review of the resulting proof before it is published in its final citable form. Please note that during the production process errors may be discovered which could affect the content, and all legal disclaimers that apply to the journal pertain.
} 
macrophages and endothelial cells, play an important role in clearance of ETX from the blood (Knolle and Gerken, 2000). Excessive levels of ETX can readily overcome this clearance mechanism leading to liver damage (Fujihara et al., 2003). This is thought to be due, in part, to oxidants, eicosanoids and cytotoxic proinflammatory cytokines released by LPS-activated macrophages and endothelial cells (Iredale, 2003; Oda et al., 2000; Su, 2002).

LPS exerts its biological activity by complexing with CD14 and toll-like receptor 4 (TLR-4) (Dobrovolskaia and Vogel, 2002; Fujihara et al., 2003; Raetz and Whitfield, 2002). These receptors belong to a family of pattern recognition receptors important in elimination of microbial pathogens (Aderem and Ulevitch, 2000). Activation of TLR-4 initiates biochemical signaling leading to increased activity of nuclear factor-kappa $\mathrm{B}(\mathrm{NF}-\mathrm{\kappa B})$ and activating protein-1 (AP-1) transcription factors and the release of cytokines such as tumor necrosis factor alpha $(\mathrm{TNF} \alpha)$ and interleukin-1 (IL-1 $\beta$ ), as well as nitric oxide, which have been implicated in tissue injury and septic shock (Raetz and Whitfield, 2002). In the absence of functional TLR-4, mice are hyporesponsive to ETX (Hoshino et al., 1999; Qureshi et al., 1999). This is associated with impaired production of inflammatory mediators and protection against ETXinduced injury (Hoshino et al., 1999; Manthey et al., 1994; Vogel et al., 1999).

In the present studies, we analyzed the role of TLR-4 in the response of liver macrophages and endothelial cells to acute endotoxemia. For these experiments, we compared the response of these cells from $\mathrm{C} 3 \mathrm{H} / \mathrm{HeJ}$ mice, which possess a mutated nonfunctional TLR-4, with control C3H/OuJ mice (Hoshino et al., 1999). Our results demonstrate that murine hepatic nonparenchymal cells contribute to hepatic responsiveness to ETX. Moreover, cellular activities are regulated in large part via TLR-4.

\section{Materials and Methods}

\section{Reagents}

Collagenase type IV, Escherichia coli LPS (serotype 0128:B12) and protein A beads (Sepharose from Staphylococcus aureus) were purchased from Sigma (St. Louis, MO). Fluorescein isothiocyanate (FITC)-labeled rat anti-mouse F4/80 and anti-mouse CD68 antibodies, FITC-labeled rat IgG control, FITC-labeled goat anti-rat IgG and Leucoperm were from Serotec (Raleigh, NC). Rat anti-mouse MECA32 was from BD Biosciences (San Diego, CA). Polyclonal rabbit anti-mouse p44/42, p38 and JNK MAP kinase and AKT antibodies were obtained from Upstate Cell Signaling (Charlottesville, VA). Horse radish peroxidase (HRP)-conjugated goat anti-rabbit antibodies was purchased from Santa Cruz Biotechnology (Santa Cruz, CA).

\section{Repurification of LPS}

LPS was repurified as previously described (Manthey et al., 1994). Briefly, LPS (2.5 mg) was reconstituted in endotoxin-free water $(500 \mu \mathrm{l})$ containing $0.2 \%$ triethylamine (TEA). Deoxycholate $(0.5 \%$, DOC) was added, followed by water-saturated phenol $(500 \mu \mathrm{l})$. The sample was then vortexed intermittently for $5 \mathrm{~min}$ and allowed to separate at room temperature for $5 \mathrm{~min}$. After an additional $5 \mathrm{~min}$ on ice, the sample was centrifuged at $4^{\circ} \mathrm{C}$ for $2 \mathrm{~min}$ at $10,000 \times \mathrm{g}$. The aqueous layer was transferred to a new tube and the phenol phase re-extracted with $500 \mu \mathrm{l}$ of $0.2 \%$ TEA/0.5\% DOC. The first and second aqueous phases were pooled and re-extracted with one $\mathrm{ml}$ of water-saturated phenol. The resulting aqueous phase was adjusted to $75 \%$ ethanol with $30 \mathrm{mM}$ sodium acetate, allowed to precipitate at $-20^{\circ} \mathrm{C}$ for one $\mathrm{hr}$ and then centrifuged for $10 \mathrm{~min}, 4^{\circ} \mathrm{C}$, at $10,000 \times \mathrm{g}$. The precipitated pellets were washed with one $\mathrm{ml}$ of cold $100 \%$ ethanol to remove remaining phenol. Nitrogen gas was used to evaporate the ethanol. LPS powder was resuspended $(5 \mathrm{mg} / \mathrm{ml})$ in $0.2 \%$ TEA and diluted to $0.25 \mathrm{mg} / \mathrm{ml}$ in PBS for animal treatments. 


\section{Animals}

Male TLR-4-mutant C3H/HeJ mice and control C3H/OuJ mice (8-12 weeks) were obtained from Jackson Laboratory (Bar Harbor, ME). All animals were housed under specific-pathogenfree conditions and allowed free access to sterile water and food. The animals received humane care in compliance with the institution's guidelines, as outlined in the Guide for the Care and Use of Laboratory Animals prepared by the National Academy of Sciences. To induce acute endotoxemia, mice were administered a single intraperitoneal dose of repurified LPS (3 mg/ $\mathrm{kg}$ ) or PBS control.

\section{Hepatic macrophage and endothelial cell isolation}

Mice were euthanized with Nembutal $(200 \mathrm{mg} / \mathrm{kg})$. Liver sinusoidal cell isolation was performed as previously described with some modifications (Ahmad et al., 1999). Briefly, the liver was perfused through the portal vein with $\mathrm{Ca}^{2+} / \mathrm{Mg}^{2+}$ - free Hanks' balanced salt solution (HBSS, pH 7.3) containing 0.5 mM EGTA and $25 \mathrm{mM}$ HEPES, followed by Leibovitz L-15 medium containing $25 \mathrm{mM}$ HEPES and $100 \mathrm{U} / \mathrm{ml}$ collagenase type IV for $2 \mathrm{~min}$. All buffers were maintained at $37^{\circ} \mathrm{C}$ during the perfusion. The liver was then extracted, disaggregated and the resulting cell suspension filtered through $220 \mu \mathrm{m}$ nylon mesh. Hepatocytes were separated from nonparenchymal cells by three successive washes $(50 \times g)$ for $5 \mathrm{~min}$. Nonparenchymal cells were recovered by centrifugation of the supernatant at $300 \times g$ for $7 \mathrm{~min}$. Macrophages and endothelial cells were then purified according to their size and density on a Beckman J-6 elutriator (Beckman Instruments Inc., Fullerton, CA) equipped with a centrifugal elutriation rotor set at $2500 \mathrm{rpm}$. The pump speed was set at $12 \mathrm{ml} / \mathrm{min}$ to load the cells. Endothelial cells were collected at $17 \mathrm{ml} / \mathrm{min}$ and macrophages at $33 \mathrm{ml} / \mathrm{min}$. The purity for macrophages and endothelial cells were about $85 \%$ as determined by flow cytometry and differential staining.

\section{Flow Cytometry and Immunofluorescence}

Macrophages $\left(1 \times 10^{6}\right)$ and endothelial cells $\left(2 \times 10^{6}\right)$ were fixed (15 min, room temperature) in $0.5 \%$ paraformaldehyde and washed in PBS containing $1 \%$ BSA. For indirect immunoflorescence assays, cells were incubated $\left(30 \mathrm{~min}, 4^{\circ} \mathrm{C}\right)$ with a $1: 10$ dilution of rat antimouse MECA32 antibody followed by incubation $\left(30 \mathrm{~min}, 4^{\circ} \mathrm{C}\right)$ with FITC-labeled goat antirat IgG. For direct immunofluorescence assays, FITC-labeled primary antibodies (F4/80 or CD68) or FITC-labeled rat IgG control were used $\left(30 \mathrm{~min}, 4^{\circ} \mathrm{C}\right)$. For analysis of CD68 expression, cells were resuspended in Leucoperm B together with the labeled antibody or control. Cells were then washed in PBS with 1\% BSA and fixed in $0.5 \%$ paraformaldehyde overnight. Forward-angle light scatter (FLS), side scatter (SS) and cell-associated fluorescence were analyzed on a Coulter Cytomics FC500 (Beckman Coulter). For each analysis, at least 15,000 events were collected and analyzed using CXP software. The percentage positive cells were calculated using Overton cumulative subtraction method of Coulter Cytometics Software.

\section{Electron Microscopy}

Liver tissue $(16 \mathrm{mg})$, macrophages $\left(2 \times 10^{6}\right)$ and endothelial cells $\left(5 \times 10^{6}\right)$ were fixed with $3 \%$ glutaraldehyde in $0.2 \mathrm{M}$ sodium cacodylate, $\mathrm{pH}$ 7.4. The specimens were then treated with $1 \%$ osmium tetroxide for one hr, followed by ethanol dehydration in graded steps through propylene oxide, and then embedded in Embed 812 (Electron Microscopy Sciences, Hatfield, PA). One micrometer sections were stained with methylene blue and azure II for light microscopic examination. Ultra-thin sections cut from representative areas were stained with uranyl acetate and lead citrate, and then examined using a Hitachi H7000 transmission electron microscope. 


\section{Electrophoretic mobility gel shift assay}

Nuclear extracts were prepared using NE-PER Nuclear and Cytoplasmic Extraction Reagents according to the manufacturer's directions (Pierce Biotechnology, Rockford, IL). Binding reactions were conducted at room temperature for $20 \mathrm{~min}$ in a total volume of $20 \mu \mathrm{l}$ containing $10 \mu \mathrm{g}$ of nuclear extracts, $4 \mu \mathrm{l}$ of $5 \mathrm{X}$ gel shift binding buffer [ $20 \%$ glycerol, $5 \mathrm{mM} \mathrm{MgCl} 2,2.5$ mM EDTA, $2.5 \mathrm{mM}$ DTT, $250 \mathrm{mM} \mathrm{NaCl}, 50 \mathrm{mM}$ Tris-HCL, $\mathrm{pH}$ 7.5], $2 \mu \mathrm{g}$ poly dI-dC, and 3 $\times 10^{4}$ counts $/ \mathrm{min} / \mathrm{ml}\left[\gamma_{-}{ }^{32} \mathrm{P}\right]$ ATP $(3,000 \mathrm{Ci} / \mathrm{mmol}$ at $10 \mathrm{mCi} / \mathrm{ml})$-labeled probe containing NF$\kappa \mathrm{B}$ (AGT TGA GGG GAC TTT CCC AGG C) or AP-1 (CGC TTG ATG ACT CAG CCG GAA) consensus oligonucleotides (Santa Cruz Biotechnologies, Santa Cruz, CA). ProteinDNA complexes were separated on $7 \%$ non-denaturing polyacrylamide gels run at $250 \mathrm{~V}$ in $0.5 \times$ TBE ( $45 \mathrm{mM}$ Trisborate and $1 \mathrm{mM}$ EDTA, $\mathrm{pH}$ 8.0), and visualized after the gels were dried and autoradiographed. For supershift assays, the reaction mixtures were pre-incubated at room temperature for $30 \mathrm{~min}$ with one $\mu \mathrm{g}$ of antibody to NF- $\mathrm{kB}$ (p65 or p50) or AP-1 (cJun or $\mathrm{cFos}$ ) subunits prior to the addition of labeled oligonucleotide. For competition assays, the reaction mixtures were incubated with a 40 -fold excess of the respective unlabeled oligonucleotide for $30 \mathrm{~min}$ prior to analysis.

\section{cDNA synthesis and real time PCR analysis}

Cells were stored in RNA LATER solution (Ambion) at $-20^{\circ} \mathrm{C}$ until RNA isolation. DNase Itreated total RNA was extracted using a RNeasy Miniprep kit (Qiagen Inc, Valencia, CA) following the manufacturer's instructions. RNA was quantified using a Nanodrop ND-1000 (Nanodrop Technologies, Wilmington, DE). For cDNA synthesis, RNA $(0.2 \mu \mathrm{g})$ in $9 \mu \mathrm{l}$ RNasefree water was denatured at $65^{\circ} \mathrm{C}$ for $4 \mathrm{~min}$, rapidly cooled on ice, and then resuspended in a $20 \mu \mathrm{l}$ final volume containing $50 \mathrm{mM}$ Tris- $\mathrm{HCl}$ (pH 8.3), $75 \mathrm{mM} \mathrm{KCl}, 3 \mathrm{mM} \mathrm{MgCl} 2,10 \mathrm{mM}$ DTT, $1 \mathrm{mM}$ of each dNTP, $20 \mathrm{mM}$ random hexamers and $200 \mathrm{U}$ Superscript II RNase $\mathrm{H}^{-}$RT (Invitrogen, Carlsbad, CA). After one hr incubation at $37^{\circ} \mathrm{C}$, RNase $\mathrm{H}^{-}(2 \mathrm{U})$ was added and the samples incubated for an additional $20 \mathrm{~min}$. The samples were then denatured at $95^{\circ} \mathrm{C}$ for 5 min and chilled on ice.

Real time quantitative PCR was performed using the ABI Prism 7000 Sequence Detection System. Each reaction contained $0.01 \mu \mathrm{g}$ cDNA template, forward and reverse primers and SYBR Green PCR master mix in a $25 \mu \mathrm{l}$ final volume. The thermal cycling parameters were set for the following conditions: one 2 -min cycle at $50^{\circ} \mathrm{C}$, one 10 -min cycle at $95^{\circ} \mathrm{C}$ (for AmpliTaq gold enzyme activation), and forty $15 \mathrm{~s}$ at $95^{\circ} \mathrm{C}$ with 1 -min at $60^{\circ} \mathrm{C}$ cycles.

Normalization for the relative quantity of mRNA was accomplished by comparison to $18 \mathrm{~S}$ rRNA. The primers used were: COX-2, GTCTGGTGCCTGGTCTGATGA and CACTCTGTTGTGCTCCCGAAG; NOS-2, GGCAGCCTGTGAGACCTTTG and GCATTGGAAGTGAAGCGTTTC; TNF $\alpha$, AAATTCGAGTGACAAGCCGTA and CCCTTGAAGAGAACCTGGGAGTAG; IL-1 $\beta$, CCAAAAGATGAAGGGCTGCT and TCATCTGGACAGCCCAGGTC; mPGE-1, GGCCTTTCTGCTCTGCAGC and GCCACCGCGTACATCTTGAT; mPGE-2, AGCCCCTGGAAGAGGTCATC and CATTCATGGCCTTCATGGGT; 5-LOX, CAGGGAGAAGCTGTCCGAGT and GCAGAGGCCGTGAAGATCAC; 12-LOX, ACCAGCAAGGACGACGTGAC and ATCAGGTAGCGACCCCATCA; and 15-LOX, TCGGAGGCAGAATTCAAGGT and CAGCAGTGGCCCAAGGTATT.

\section{Western Blotting}

Cells were lysed in buffer containing $1 \%$ Igepal, $0.5 \%$ sodium deoxycholate, $0.1 \%$ SDS, $1 \%$ protease inhibitor and $1 \%$ phosphatase inhibitors in PBS. Lysates were clarified by centrifugation at $16,000 \mathrm{~g}$ for $10 \mathrm{~min}$ at $4^{\circ} \mathrm{C}$. Protein concentrations were measured using a BCA protein assay kit (Pierce Biotechnology, Inc., Rockford, IL). Samples were fractioned on 
10\% SDS-polyacrylamide gels and transferred to nitrocellulose (Amersham Biosciences, Piscataway, NJ). Nonspecific binding was blocked using 5\% milk in Tris-buffered saline with $0.1 \%$ Tween 20 (TBS-Tween 20 ). The membrane was then incubated overnight $\left(4^{\circ} \mathrm{C}\right)$ with primary antibody in $1 \%$ milk (in TBS-Tween 20); washed for one hr using TBS-Tween 20, and then incubated for one hr with secondary antibody (1:5000) in 2.5\% milk (in TBS-Tween 20). Antibody binding was visualized by autoradiography using enhanced chemiluminescence ECL detection reagents (Amersham Life Science, Arlington Heights, IL). The dilutions of primary antibodies were as followed: p38, p44/42 and JNK MAP kinases and AKT (1:1300); and phospho-p38, phospho-p44/42 and phospho-JNK MAP kinases and phospho-AKT (1:1000). Ten micrograms of protein were loaded onto each lane of the gel.

\section{Statistics}

All experiments were repeated at least three times using four mice per treatment group. Data were analyzed by one-way analysis of variance using SigmaStat 3.5. A $P$ value of $\leq 0.05$ was considered statistically significant.

\section{Results}

\section{Effects of acute endotoxemia on the physical and antigenic properties of liver macrophages and endothelial cells}

Initially, we analyzed the effects of acute endotoxemia on the morphology of liver macrophages and endothelial cells in situ. Examination of liver sections from untreated $\mathrm{C} 3 \mathrm{H} / \mathrm{OuJ}$ mice by electron microscopy revealed a relatively large nuclear region and numerous cytoplasmic vacuoles in both macrophages and endothelial cells (Fig. 1). Endothelial cells also displayed long thin attenuated cytoplasmic processes. The greatest morphologic effects of ETX administration were observed $3 \mathrm{hr}$ post treatment (Fig. 1, panels C and D). At this time increased numbers of vacuoles were observed in macrophages and endothelial cells. In endothelial cells, lipid droplets were also evident, suggesting cellular damage (Van Bossuyt and Wisse, 1988). Macrophages and neutrophils containing lysosomal granules were also apparent in the sinusoids. By $24 \mathrm{hr}$ post treatment (Fig. 1, panels E and F), the morphology of the cells resembled control.

We next analyzed the morphology of macrophages and endothelial cells isolated from livers of control and ETX treated mice. Light microscopic analysis indicated that macrophages from both control and ETX treated mice were in general, larger than endothelial cells and possessed a greater cytoplasmic to nuclear ratio (Fig. 2, panels A-D). After $6 \mathrm{hr}$ incubation (Fig. 2, panels E-H), both macrophages and endothelial cells flattened and spread on the culture dishes, and exhibited stellate morphology. Following ETX treatment of the mice, both freshly isolated and cultured macrophages appeared more irregularly shaped. In contrast to macrophages, no major structural changes were noted in endothelial cells after ETX administration. Electron microscopic evaluation confirmed that freshly isolated macrophages were relatively round with projecting microvilli and pseudopodia, while endothelial cells appeared as clusters of folded cell processes around the cell body (Fig. 3). Macrophages and endothelial cells isolated from ETX treated mice were significantly more vacuolated than cells from control animals and displayed increased lysosomal density. The folded processes of the endothelial cells were also less attenuated and contracted into the cell body.

In further studies, we analyzed the effects of acute endotoxemia on the physical properties of liver macrophages and endothelial cells by flow cytometric assessment of their light-scattering properties. In general, light scattered in the forward-angle direction is proportional to the size of the cells, and in the right-angle direction (side scatter), to the density or granularity of the cells. Flow cytometric analysis revealed one relatively homogeneous population of endothelial 
cells (Fig. 4, left panel). In contrast, two subpopulations of macrophages were identified (Fig. 4, left panel); one population ( $58 \pm 0.02 \%$ ) that was relatively small in size and density (subpopulation 1) and a second population $(42 \pm 0.02 \%)$ that was larger and more dense (subpopulation 2). Whereas ETX treatment of mice had no major effects on the light-scattering properties of endothelial cells (Fig. 4), marked changes were noted in the macrophages (Fig. 4). Thus, following ETX administration, the percentage of macrophages in subpopulation 1 increased, while the percentage of cells in subpopulation 2 decreased. This became evident with ETX treatment. At this time, $70 \pm 0.9 \%$ of the macrophages were contained within subpopulation 1, and $30 \pm 0.9 \%$ in subpopulation 2 .

To confirm their identity, cells were stained with antibodies to the macrophage markers, F4/80 and CD68 (Gordon, 1999; Rabinowitz and Gordon, 1991), or the endothelial cell marker, MECA32 (Penn et al., 1993), and then analyzed by flow cytometry. Approximately 85\% of macrophages from control animals stained positively for F4/80, and 80\% for CD68 (Fig. 5). Binding of F4/80 to the cells was homogeneous, indicating that both macrophage subpopulations expressed similar levels of this antigen. In contrast, two populations of macrophages expressing relatively low and high levels of CD68 were identified. Whereas the low $\mathrm{CD}^{+} 8^{+}$cells were distributed equally in subpopulations 1 and 2 , the majority of cells (70\%) expressing high levels of CD68 were from the smaller and less dense macrophage population (subpopulation 1). Interestingly, approximately $40 \%$ of liver macrophages were also found to express low levels of the endothelial cell marker, MECA32. The majority of these cells were from subpopulation 2, the larger denser macrophage population. Treatment of mice with ETX had no major effects on expression of F4/80, CD68 or MECA32 by the macrophages (Fig. 5). We also analyzed expression of these antigens on liver endothelial cells. The majority of endothelial cells $(85 \%)$ from both control and ETX treated mice were identified as positive for MECA32. Endothelial cells were also found to express F4/80 and CD68; however the percentage positive cells and the intensity of fluorescence were reduced when compared to macrophages. Thus, about $25 \%$ of the endothelial cells were positive for $\mathrm{F} 4 / 80$ and $65 \%$ for CD68. As observed in macrophages, ETX administration had no effect on expression of these antigens by endothelial cells.

\section{Role of TLR-4 in liver macrophage and endothelial cell responsiveness to ETX}

We have previously demonstrated that acute endotoxemia is associated with functional activation of liver macrophages and endothelial cells (Ahmad et al., 2002; Feder and Laskin, 1994; McCloskey et al., 1992; Pilaro and Laskin, 1986). To determine if TLR-4 plays a role in the response of these cells to ETX, we compared C3H/OuJ mice with $\mathrm{C} 3 \mathrm{H} / \mathrm{HeJ}$ mice, which possess a mutated nonfunctional TLR-4 (Hoshino et al., 1999). As observed in C3H/OuJ mice, two subpopulations of liver macrophages were identified in control $\mathrm{C} 3 \mathrm{H} / \mathrm{HeJ}$ mice that differ with respect to size and density (Fig. 4, right panel). Subpopulation $1(57 \pm 1.2 \%)$ was relatively small in size and density, while subpopulation $2(43 \pm 1.2 \%)$ was larger and more dense. In contrast to $\mathrm{C} 3 \mathrm{H} / \mathrm{OuJ}$ mice, ETX had no major effects on macrophages from $\mathrm{C} 3 \mathrm{H} / \mathrm{HeJ}$ mice (Fig. 4). Flow cytometric analysis also revealed one relatively homogeneous population of endothelial cells from control and ETX treated $\mathrm{C} 3 \mathrm{H} / \mathrm{HeJ}$ mice, which is similar to findings in $\mathrm{C} 3 \mathrm{H} / \mathrm{OuJ}$ mice.

We also analyzed the effects of ETX on the phenotype of macrophages and endothelial cells from TLR-4 mutant mice. As observed in cells from C3H/OuJ mice, in cells from both control and ETX treated $\mathrm{C} 3 \mathrm{H} / \mathrm{HeJ}$ mice; one homogenous population of $\mathrm{F} 4 / 80^{+}$macrophages was identified whereas two subpopulations of macrophages, binding low and high levels of CD68 were noted (Fig. 6). Moreover, approximately $45 \%$ of liver macrophages from the mutant mice were also found to express the endothelial cell marker, MECA32. Endothelial cells from C3H/ $\mathrm{HeJ}$ mice, like $\mathrm{C} 3 \mathrm{H} / \mathrm{OuJ}$ mice, were highly positive (80\%) for MECA32. These cells also 
expressed F4/80 and CD68 although at reduced level when compared to macrophages. Thus, approximately $40 \%$ of endothelial cells were positive for F4/80 and 20\% for CD68. ETX administration had no effect on expression of these markers in endothelial cells from $\mathrm{C} 3 \mathrm{H} / \mathrm{HeJ}$ mice.

The effects of acute endotoxemia on the number of macrophages and endothelial cells recovered from the liver were also assessed. ETX administration to $\mathrm{C} 3 \mathrm{H} / \mathrm{OuJ}$ resulted in a twofold increase in the number of macrophages recovered from the liver $48 \mathrm{hr}$ post treatment when compared to control mice (Table 1). In contrast, although two- to three-fold greater numbers of endothelial cells were recovered from the liver relative to macrophages, ETX had no effect on numbers of these cells. In $\mathrm{C} 3 \mathrm{H} / \mathrm{HeJ}$ mice, ETX had no effect on number of macrophages or endothelial cells recovered from the livers (Table 1). Microscopic analysis of macrophages and endothelial cells isolated from $\mathrm{C} 3 \mathrm{H} / \mathrm{HeJ}$ mice treated with ETX also showed no major changes when compared to control mice (data not shown).

\section{Effects of acute endotoxemia on inflammatory gene expression}

In further studies, we analyzed the role of TLR-4 in macrophage and endothelial cell mRNA expression of nitric oxide synthase-2 (NOS-2), TNF $\alpha$ and IL-1 $\beta$, inflammatory proteins important in the liver response to ETX (Jirillo et al., 2002). Induction of acute endotoxemia was associated with a rapid and transient increase in expression of these genes in both macrophages and endothelial cells from control C3H/OuJ mice. This was evident within $3 \mathrm{hr}$ and decreased toward control by $24 \mathrm{hr}$ (Fig. 7). Whereas macrophages expressed greater levels of NOS-2 and TNF $\alpha$, when compared to endothelial cells, levels of IL-1 $\beta$ were similar in the two cell types. In $\mathrm{C} 3 \mathrm{H} / \mathrm{HeJ}$ mice, acute endotoxemia had minimal effects on expression of these inflammatory mediators.

Cyclooxygenase-2 (COX-2), microsomal PGE synthases (mPGES-1 and mPGES-2) and lipoxygenases (5-LOX, 12-LOX and 15-LOX) are enzymes mediating the biosynthesis of eicosanoids, which are important in liver inflammation and cellular proliferation during acute endotoxemia (Titos et al., 2005; Uematsu et al., 2002). Treatment of C3H/OuJ mice with ETX resulted in a marked induction of COX-2 and mPGES-1 mRNA expression within $3 \mathrm{hr}$ in both macrophages and endothelial cells (Fig. 8). These effects were transient returning to control by $24 \mathrm{hr}$. 5-LOX mRNA was also found to increase after ETX administration but only in endothelial cells. In contrast, 15-LOX mRNA expression decreased (7-fold) in endothelial cells, which was evident within $3 \mathrm{hr}$ post ETX administration. Acute endotoxemia had no significant effects on mPGES-2 or 12-LOX mRNA expression in either cell type. In general, in $\mathrm{C} 3 \mathrm{H} / \mathrm{HeJ}$ mice, no effects were observed in the expression of eicosanoid metabolism genes, with exception to mPGES-1, which increased 12-fold in macrophages and 3-fold in endothelial cells after ETX administration (Figs. 7 and 8).

\section{Effects of acute endotoxemia on NF-KB and AP-1 nuclear binding activity}

The transcription factors NF- $\mathrm{KB}$ and AP-1 are known to regulate expression of variety of genes involved in inflammation and immune responses, including IL- $1 \beta$, TNF $\alpha$, NOS-2 and COX-2 (Blackwell and Christman, 1997; Karin et al., 1997). In further studies, we determined if acute endotoxemia was associated with altered nuclear binding activity of these transcription factors in macrophages and endothelial cells, and if this was dependent on TLR-4. Constitutive NF$\kappa \mathrm{B}$ and $\mathrm{AP}-1$ nuclear binding activity was detectable in macrophages and endothelial cells from control C3H/OuJ mice (Fig. 9). In both cell types, ETX administration resulted in a rapid increase in nuclear binding of the transcription factors, which was noted within $3 \mathrm{hr}$. Whereas in macrophages, transcription factor activity subsequently returned to control levels, in endothelial cells, NF- $\mathrm{KB}$ and AP-1 binding activity persisted for at least $24 \mathrm{hr}$. Note that in both macrophages and endothelial cells, ETX altered the migration of AP-1 in the gels. This 
is likely due to ETX-induced alterations in the composition of proteins in the AP-1 complex (Karin et al., 1997). This might contribute to different functional activities in these cells. NF$\kappa \mathrm{B}$ and $\mathrm{AP}-1$ nuclear binding activity was blocked by incubating the samples with 40 -fold excess of the respective unlabeled probes, demonstrating the specificity of the probes. Moreover, supershift assays using antibodies to $\mathrm{p} 50$ and p65 blocked NF- $\mathrm{\kappa B}$ binding activity. Similarly, c-Jun antibody partially blocked AP-1 binding activity. As observed in C3H/OuJ mice, in C3H/HeJ TLR-4 mutant mice, low constitutive NF- $\mathrm{kB}$ and AP-1 nuclear binding activity was detectable in both macrophages and endothelial cells (Fig. 9). However, acute endotoxemia had no effect on this activity.

\section{Effects of acute endotoxemia on mitogen activity protein (MAP) kinase and protein kinase B (AKT) expression in macrophages and endothelial cells}

MAP kinases and AKT are signaling molecules important in regulating expression of inflammatory genes (Guha and Mackman, 2002; Saklatvala, 2004). In further studies, we analyzed the effects of acute endotoxemia on expression of c-Jun $\mathrm{NH}_{2}$-terminal kinase (JNK), extracellular signal-regulated kinase 1 and 2 (p44/42) and p38 MAP kinase, and AKT in liver sinusoidal cells. Freshly isolated liver macrophages and endothelial cells from both $\mathrm{C} 3 \mathrm{H} / \mathrm{OuJ}$ and $\mathrm{C} 3 \mathrm{H} / \mathrm{HeJ}$ mice were found to constitutively express each of the MAP kinase proteins, as well as AKT (Fig. 10). ETX administration had no major effects on expression of these proteins in either cell type or mouse strain. In macrophages from $\mathrm{C} 3 \mathrm{H} / \mathrm{OuJ}$ mice, ETX administration caused an increase in phospho-JNK and phospho-p38 MAP kinase. In these cells, phosphop44/42 MAP kinase and phospho-AKT were constitutively elevated in both control and endotoxin-treated mice. In contrast, in endothelial cells from $\mathrm{C} 3 \mathrm{H} / \mathrm{OuJ}$ mice, all three MAP kinases and AKT were constitutively activated. Moreover, while ETX transiently increased activation of p38 MAP kinase in endothelial cells at $3 \mathrm{hr}$, p44/42 MAP kinase and AKT transiently decreased. The MAP kinases and AKT were also constitutively activated in the macrophages and endothelial cells from $\mathrm{C} 3 \mathrm{H} / \mathrm{HeJ}$ mice. ETX administration resulted in an increase in phospho-p38 MAP kinase in macrophages, which was evident at $24 \mathrm{hr}$. No further changes in activation of the MAP kinases or AKT were observed in endothelial cells from $\mathrm{C} 3 \mathrm{H} / \mathrm{HeJ}$ mice following endotoxin administration.

\section{Discussion}

Liver macrophages and endothelial cells have been implicated in the pathophysiology of ETXinduced hepatic injury (Oda et al., 2000; Su, 2002). This is due in part to excessive production of inflammatory mediators by these cells. In the present studies, we analyzed the role of TLR-4 in the response of these liver sinusoidal cells to acute endotoxemia. Both macrophages and endothelial cells were found to undergo a process of cellular activation after in vivo exposure to ETX. This was characterized by physical and functional alterations, including increased expression of proinflammatory and cytotoxic mediators and regulatory signaling molecules. However, these responses were not observed or were greatly reduced in $\mathrm{C} 3 \mathrm{H} / \mathrm{HeJ}$ mice, which possess a mutated nonfunctional TLR-4. These findings demonstrate that TLR-4 signaling plays an important role in ETX-induced activation of liver nonparenchymal cells.

Light and electron microscopy revealed that macrophages from control mice were larger than endothelial cells, and exhibited greater cytoplasmic to nuclear ratio. Moreover, whereas macrophages possessed short microvilli, long thin fenestrated cytoplasmic extensions were noted in endothelial cells. These morphologic differences are consistent with previous reports on macrophages and endothelial cells from rat and human liver (Carr, 1973; Gendrault JL 1988). After incubation for $6 \mathrm{hr}$, both macrophages and endothelial cells flattened and spread on the culture dishes and displayed stellate morphology. Similar findings have been described in rat liver macrophages and endothelial cells (McCloskey et al., 1992). Like rat macrophages 
(Ahmad et al., 1999), mouse macrophages were heterogeneous with respect to size and density. These results are in accord with reports of macrophage heterogeneity within the liver lobules (Kono et al., 2002; Laskin et al., 2001a). Macrophage heterogeneity was also observed in antigen expression. Thus, subpopulations of macrophages that expressed relatively high and low levels of CD68 were identified. Flow cytometric analysis of these cells demonstrated that the high CD68 expressing cells consisted mainly of small macrophages, which are thought to reside in centrilobular regions of the liver (Bouwens et al., 1986; Sleyster and Knook, 1982). It has been suggested that CD68 is important in scavenging oxidized low-density lipoprotein (oxLDL) (Kurushima et al., 2000). Higher expression of CD68 on macrophages in the centrilobular regions of the liver may facilitate the removal of oxLDL from the portal circulation. F4/80 is highly expressed on mature macrophages with little subpopulation heterogeneity (Hirsch et al., 1981). Similarly we found that F4/80 expression on resident liver macrophages was homogeneous. Interestingly, endothelial cells were found to express CD68 and F4/80 antigens, although at reduced levels when compared to macrophages. These findings, together with our observation that macrophages express low levels of the endothelial cell protein MECA32, provide support for the idea that liver macrophages and endothelial cells share some similar phenotypic characteristics (Knolle et al., 1999; McCloskey et al., 1992).

Although treatment of mice with ETX had no major effects on CD68, F4/80 or MECA32 expression by macrophages or endothelial cells, morphological evidence of macrophage activation was noted, which is consistent with previous studies in rats (McCloskey et al., 1992; Van Bossuyt and Wisse, 1988). Thus, macrophages isolated from ETX treated mice were significantly more vacuolated than cells from control animals and displayed increased lysosomal density. We also noted increases in the percentage of a small dense macrophage population (subpopulation 1) after ETX administration. In previous studies with rats, the smaller dense macrophages were shown to be activated to produce increased amounts of cytokines and oxidants when compared to the larger macrophages and it is likely that these cells function similarly in mice (Ahmad et al., 1999; Itoh et al., 1992). Consistent with previous studies in rats, ETX administration to $\mathrm{C} 3 \mathrm{H} / \mathrm{OuJ}$ mice was found to be associated with an increase in the number of macrophages, but not endothelial cells, recovered from the liver (Ahmad et al., 1999; McCloskey et al., 1992; Van Bossuyt and Wisse, 1988). This is most likely due to infiltration of macrophages into the liver from blood and bone marrow precursors.

To assess the role of TLR-4 in the liver nonparenchymal cell response to ETX, we used C3H/ HeJ TLR-4 mutant mice. In contrast to $\mathrm{C} 3 \mathrm{H} / \mathrm{OuJ}$ mice, ETX had no major effects on the light scattering properties of macrophages from $\mathrm{C} 3 \mathrm{H} / \mathrm{HeJ}$ mice or the number of macrophages recovered from liver. These data suggest that TLR-4 plays an important role in leukocyte trafficking into the liver during acute endotoxemia. This is supported by studies demonstrating that the lack of functional TLR-4 impairs processes required for recruitment of leukocytes into the liver, lung and muscle (Andonegui et al., 2002; Kerfoot and Kubes, 2005).

$\mathrm{NF}-\kappa \mathrm{B}$ and AP-1 are important transcriptional regulators of inflammatory genes, a number of which have been implicated in ETX-induced hepatotoxicity (Cohen, 2002; Fujihara et al., 2003; $\mathrm{Su}, 2002)$. The present studies demonstrate that both NF- $\kappa \mathrm{B}$ and AP-1 nuclear binding activity are upregulated in liver macrophages and endothelial cells within $3 \mathrm{hr}$ of ETX administration to $\mathrm{C} 3 \mathrm{H} / \mathrm{OuJ}$ mice. A similar rapid activation of $\mathrm{NF}-\kappa \mathrm{B}$ and $\mathrm{AP}-1$ in response to ETX has been previously described in intact rat liver (Li et al., 2006). Interestingly, lower constitutive levels of NF- $\kappa \mathrm{B}$ and AP-1 activity were detected in both liver macrophages and endothelial cells from control mice. This is most likely due to continuous exposure of these cells to gut-derived ETX through the portal circulation.

In $\mathrm{C} 3 \mathrm{H} / \mathrm{OuJ}$ mice, increased $\mathrm{NF}-\kappa \mathrm{B}$ and AP-1 nuclear binding activity after ETX administration was correlated with increased expression of NOS-2, IL-1 $\beta$, TNF $\alpha$, COX-2 and 
mPGES-1 mRNA in both macrophages and endothelial cells. Interestingly, whereas ETXinduced inflammatory gene expression and transcription factor activity returned to control levels in macrophages after $3 \mathrm{hr}$, in endothelial cells they persisted for at least $24 \mathrm{hr}$. These findings are consistent with the idea that endothelial cells play a more prominent role late in the inflammatory response to ETX (Knolle and Gerken, 2000). Recent studies have shown that inhibition of NF-kprevents ETX-induced inflammatory mediator production, including TNF $\alpha$ and IL-6, in intact liver (Li et al., 2006). These data suggest that inflammatory gene expression in liver sinusoidal cells is dependent on activation of NF-KB. Proteins encoded by inflammatory genes, including NOS-2, COX-2, TNF $\alpha$ and IL- $1 \beta$ aid in host defense against microbial infection and may also contribute to tissue injury (Cohen, 2002; Laskin et al., 2001b; Lin and Yeh, 2005). Prostaglandins generated via COX-2 and mPGES-1 are also involved in vasodilation, chemotaxis and the generation of inflammatory cytokines (Fahmi, 2004; Park and Christman, 2006). Findings that these genes are upregulated in liver macrophages and endothelial cells provide support for the idea that these cells are important effectors of ETX-induced hepatic inflammation. Of note is our observation that hepatic endothelial cells expressed similar levels of TNF $\alpha$ as macrophages. TNF $\alpha$ has been reported to be primarily expressed by activated monocyte/macrophages (Xiong and Hales, 1993). These data support the idea that endothelial cells and macrophages in the liver exhibit similar phenotypic and functional reactivity during acute endotoxemia. Our findings that COX-2 and mPGES-1, but not mPGES-2, are upregulated by ETX are in accord with studies in isolated rat liver macrophages treated with LPS (Bezugla et al., 2006).

The present studies also showed that 5-LOX mRNA expression is increased after ETX administration, but only in endothelial cells. A similar lack of effect of LPS on 5-LOX has been described in cultured alveolar and peritoneal macrophages (Brock et al., 2003; Coffey et al., 2000). 5-LOX catalyzes the production of leukotrienes, which are known to be important in leukocyte activation, promoting adhesion of these cells to vascular endothelium, and stimulating chemotaxis and the production of proinflammatory cytokines (Goetzl et al., 1995; Peters-Golden et al., 2005). The observation that 5-LOX is expressed in liver endothelial cells provides additional support for the idea that these cells play a role in recruitment and activation of leukocytes into liver tissue during acute endotoxemia (Kerfoot and Kubes, 2005; Oda et al., 2000). Of interest is our finding that 15-LOX decreases in endothelial cells after ETX administration. Leukotrienes produced via 15-LOX have been reported to inhibit neutrophil migration across cytokine-activated endothelium, and to block the generation of superoxide anion (Kuhn et al., 2002). These data suggest that 15-LOX is important in limiting the inflammatory response and it may play a similar role in the liver.

In contrast to $\mathrm{C} 3 \mathrm{H} / \mathrm{OuJ}$ mice, ETX administration to $\mathrm{C} 3 \mathrm{H} / \mathrm{HeJ}$ mice had minimal effects on NF- $\mathrm{KB}$ and AP-1 nuclear binding activity, or on NOS-2, IL-1 $\beta$, TNF $\alpha$ and COX-2 mRNA expression in macrophages and endothelial cells. Similar defects in LPS-induced inflammatory genes (mPGES-1, TNF $\alpha, \mathrm{COX}-2$ ) and nuclear transcription factor binding activity (NF- $\mathrm{\kappa B}$ ) have been described in peritoneal macrophages from $\mathrm{C} 3 \mathrm{H} / \mathrm{HeJ}$ mice, confirming the importance of TLR-4 in ETX responsiveness (Uematsu et al., 2002; Vogel and Fenton, 2003). Interestingly, mPGES-1 was induced to a relatively small extent in both cell types from these mice. This suggests that multiple signaling pathways regulate expression of this gene in hepatic nonparenchymal cells. Of note, low levels of constitutive NF- $\mathrm{BB}$ and AP-1 binding activity were detected in $\mathrm{C} 3 \mathrm{H} / \mathrm{HeJ}$ mice indicating that this activity may not require TLR-4 signaling during homeostasis.

MAP kinases and AKT are signaling molecules important in regulating expression of inflammatory genes, including NOS-2 and COX-2 (Chen et al., 1999; Saklatvala, 2004; Schabbauer et al., 2004). Interestingly, these kinases were constitutively active in macrophages and endothelial cells from $\mathrm{C} 3 \mathrm{H} / \mathrm{HeJ}$ mice and, in general, not altered by ETX administration. 
These data suggest that TLR-4 is only partially involved in expression and activation of these kinases. Lack of functional TLR-4 may be compensated by the presence of IL-1R. These receptors contain homologous cytoplasmic domain and thus, may induce similar intracellular pathways culminating in constitutive MAP kinases and AKT activation (Aderem and Ulevitch, 2000; Martin and Wesche, 2002; Qureshi et al., 1999). In macrophages and endothelial cells from $\mathrm{C} 3 \mathrm{H} / \mathrm{OuJ}$ mice, p44/42 MAP kinase and AKT were also constitutively activated whereas JNK was activated only in endothelial cells. Administration of ETX was found to activate JNK and p38 MAP kinases in macrophages, and of p38 MAP kinase in endothelial cells. A decrease was also noted in activated p44/42 MAP kinase and AKT in endothelial cells. These data indicate that only JNK in macrophages and p38 in macrophages and endothelial cells are modulated by ETX in $\mathrm{C} 3 \mathrm{H} / \mathrm{OuJ}$ mice and that these enzymes may be required for functional activation of the cells. PI3-kinase-AKT pathway has been shown to negatively regulate LPSinduced expression of TNF $\alpha$ and NOS-2. Decreased activated AKT in endothelial cells may mediate the increases in inflammatory gene expression observed in these cells in our studies (Park et al., 1997; Schabbauer et al., 2004). Taken together, it appears that in macrophages ETX-induced TLR-4 signaling pathways involves JNK MAP kinase, while in endothelial cells p38 MAP kinase is important.

TLR-4 participates in host defense against invading pathogens (Aderem and Ulevitch, 2000). Our data provides evidence that ETX utilizes TLR-4 for activation of intracellular signals, including MAP kinases and nuclear binding factors (NF- $\mathrm{KB}$ and/or AP-1) and upregulation of inflammatory genes in liver nonparenchymal cells. Moreover, TLR-4 appears to be required for recruitment of macrophages into the liver during acute endotoxemia. These findings suggest that TLR-4 may be a useful target for developing therapeutic interventions aimed at controlling ETX-induced liver injury.

\section{Acknowledgments}

The authors express gratitude to Samantha Liu, Tim Coffin and Angie Groves for their valuable technical assistance.

Grants

Research described in this article was supported by NIH Grants GM034310, ES004738, AR055073, ES005022 and CA100994.

\section{References}

Aderem A, Ulevitch RJ. Toll-like receptors in the induction of the innate immune response. Nature 2000;406:782-7. [PubMed: 10963608]

Ahmad N, Chen LC, Gordon MA, Laskin JD, Laskin DL. Regulation of cyclooxygenase-2 by nitric oxide in activated hepatic macrophages during acute endotoxemia. J Leukoc Biol 2002;71:1005-11. [PubMed: 12050186]

Ahmad N, Gardner CR, Yurkow EJ, Laskin DL. Inhibition of macrophages with gadolinium chloride alters intercellular adhesion molecule-1 expression in the liver during acute endotoxemia in rats. Hepatology 1999;29:728-36. [PubMed: 10051474]

Andonegui G, Goyert SM, Kubes P. Lipopolysaccharide-induced leukocyte-endothelial cell interactions: a role for CD14 versus toll-like receptor 4 within microvessels. J Immunol 2002;169:2111-9. [PubMed: 12165539]

Bezugla Y, Kolada A, Kamionka S, Bernard B, Scheibe R, Dieter P. COX-1 and COX-2 contribute differentially to the LPS-induced release of PGE2 and TxA2 in liver macrophages. Prostaglandins Other Lipid Mediat 2006;79:93-100. [PubMed: 16516813]

Blackwell TS, Christman JW. The role of nuclear factor-kappa B in cytokine gene regulation. Am J Respir Cell Mol Biol 1997;17:3-9. [PubMed: 9224203]

Bouwens L, Baekeland M, De Zanger R, Wisse E. Quantitation, tissue distribution and proliferation kinetics of Kupffer cells in normal rat liver. Hepatology 1986;6:718-22. [PubMed: 3733004] 
Brock TG, McNish RW, Mancuso P, Coffey MJ, Peters-Golden M. Prolonged lipopolysaccharide inhibits leukotriene synthesis in peritoneal macrophages: mediation by nitric oxide and prostaglandins. Prostaglandins Other Lipid Mediat 2003;71:131-45. [PubMed: 14518557]

Carr, I. The Macrophages: A Review of Ultrastructure and Function. Academic Press; New York: 1973.

Chen C, Chen YH, Lin WW. Involvement of p38 mitogen-activated protein kinase in lipopolysaccharideinduced iNOS and COX-2 expression in J774 macrophages. Immunology 1999;97:124-9. [PubMed: 10447723]

Coffey MJ, Phare SM, Peters-Golden M. Prolonged exposure to lipopolysaccharide inhibits macrophage 5-lipoxygenase metabolism via induction of nitric oxide synthesis. J Immunol 2000;165:3592-8. [PubMed: 11034360]

Cohen J. The immunopathogenesis of sepsis. Nature 2002;420:885-91. [PubMed: 12490963]

Dobrovolskaia MA, Vogel SN. Toll receptors, CD14, and macrophage activation and deactivation by LPS. Microbes Infect 2002;4:903-14. [PubMed: 12106783]

Fahmi H. mPGES-1 as a novel target for arthritis. Curr Opin Rheumatol 2004;16:623-7. [PubMed: 15314505]

Feder LS, Laskin DL. Regulation of hepatic endothelial cell and macrophage proliferation and nitric oxide production by GM-CSF, M-CSF, and IL-1 beta following acute endotoxemia. J Leukoc Biol 1994;55:507-13. [PubMed: 8145021]

Fujihara M, Muroi M, Tanamoto K, Suzuki T, Azuma H, Ikeda H. Molecular mechanisms of macrophage activation and deactivation by lipopolysaccharide: roles of the receptor complex. Pharmacol Ther 2003;100:171-94. [PubMed: 14609719]

Gendrault, JLSA.; Bingen, A.; Kirin, A. Kupffer and Endothelial Cells. In: Bioulac-Sage, BCP., editor. Sinusoids in Human Liver: Health and Disease. Kupffer Cell Foundation; Hv Rijswijk, The Netherlands: 1988. p. 17-38.

Goetzl EJ, An S, Smith WL. Specificity of expression and effects of eicosanoid mediators in normal physiology and human diseases. Faseb J 1995;9:1051-8. [PubMed: 7649404]

Gordon S. Macrophage-restricted molecules: role in differentiation and activation. Immunol Lett 1999;65:5-8. [PubMed: 10065619]

Guha M, Mackman N. The phosphatidylinositol 3-kinase-Akt pathway limits lipopolysaccharide activation of signaling pathways and expression of inflammatory mediators in human monocytic cells. J Biol Chem 2002;277:32124-32. [PubMed: 12052830]

Hirsch S, Austyn JM, Gordon S. Expression of the macrophage-specific antigen F4/80 during differentiation of mouse bone marrow cells in culture. J Exp Med 1981;154:713-25. [PubMed: 7276827]

Hoshino K, Takeuchi O, Kawai T, Sanjo H, Ogawa T, Takeda Y, Takeda K, Akira S. Cutting edge: Tolllike receptor 4 (TLR4)-deficient mice are hyporesponsive to lipopolysaccharide: evidence for TLR4 as the Lps gene product. J Immunol 1999;162:3749-52. [PubMed: 10201887]

Iredale JP. Regulating hepatic inflammation: pathogen-associated molecular patterns take their toll. Hepatology 2003;37:979-82. [PubMed: 12717378]

Itoh Y, Okanoue T, Morimoto M, Nagao Y, Mori T, Hori N, Kagawa K, Kashima K. Functional heterogeneity of rat liver macrophages: interleukin-1 secretion and Ia antigen expression in contrast with phagocytic activity. Liver 1992;12:26-33. [PubMed: 1564982]

Jirillo E, Caccavo D, Magrone T, Piccigallo E, Amati L, Lembo A, Kalis C, Gumenscheimer M. The role of the liver in the response to LPS: experimental and clinical findings. J Endotoxin Res 2002;8:31927. [PubMed: 12537690]

Karin M, Liu Z, Zandi E. AP-1 function and regulation. Curr Opin Cell Biol 1997;9:240-6. [PubMed: 9069263]

Kerfoot SM, Kubes P. Local coordination verses systemic disregulation: complexities in leukocyte recruitment revealed by local and systemic activation of TLR4 in vivo. J Leukoc Biol 2005;77:8627. [PubMed: 15743884]

Knolle PA, Gerken G. Local control of the immune response in the liver. Immunol Rev 2000;174:2134. [PubMed: 10807504] 
Knolle PA, Germann T, Treichel U, Uhrig A, Schmitt E, Hegenbarth S, Lohse AW, Gerken G. Endotoxin down-regulates $\mathrm{T}$ cell activation by antigen-presenting liver sinusoidal endothelial cells. J Immunol 1999;162:1401-7. [PubMed: 9973395]

Kono H, Fujii H, Asakawa M, Yamamoto M, Maki A, Matsuda M, Rusyn I, Matsumoto Y. Functional heterogeneity of the kupffer cell population is involved in the mechanism of gadolinium chloride in rats administered endotoxin. J Surg Res 2002;106:179-87. [PubMed: 12127824]

Kuhn H, Walther M, Kuban RJ. Mammalian arachidonate 15-lipoxygenases structure, function, and biological implications. Prostaglandins Other Lipid Mediat 2002;68-69:263-90.

Kurushima H, Ramprasad M, Kondratenko N, Foster DM, Quehenberger O, Steinberg D. Surface expression and rapid internalization of macrosialin (mouse CD68) on elicited mouse peritoneal macrophages. J Leukoc Biol 2000;67:104-8. [PubMed: 10648004]

Laskin DL, Weinberger B, Laskin JD. Functional heterogeneity in liver and lung macrophages. J Leukoc Biol 2001a;70:163-70. [PubMed: 11493607]

Laskin JD, Heck DE, Gardner CR, Laskin DL. Prooxidant and antioxidant functions of nitric oxide in liver toxicity. Antioxid Redox Signal 2001b;3:261-71. [PubMed: 11396480]

Li G, Qi XP, Wu XY, Liu FK, Xu Z, Chen C, Yang XD, Sun Z, Li JS. Verapamil modulates LPS-induced cytokine production via inhibition of NF-kappa B activation in the liver. Inflamm Res 2006;55:10813. [PubMed: 16673153]

Lin WJ, Yeh WC. Implication of Toll-like receptor and tumor necrosis factor alpha signaling in septic shock. Shock 2005;24:206-9. [PubMed: 16135957]

Manthey CL, Perera PY, Henricson BE, Hamilton TA, Qureshi N, Vogel SN. Endotoxin-induced early gene expression in C3H/HeJ (Lpsd) macrophages. J Immunol 1994;153:2653-63. [PubMed: 7521367]

Martin MU, Wesche H. Summary and comparison of the signaling mechanisms of the Toll/interleukin-1 receptor family. Biochim Biophys Acta 2002;1592:265-80. [PubMed: 12421671]

McCloskey TW, Todaro JA, Laskin DL. Lipopolysaccharide treatment of rats alters antigen expression and oxidative metabolism in hepatic macrophages and endothelial cells. Hepatology 1992;16:191203. [PubMed: 1319950]

Oda M, Han JY, Nakamura M. Endothelial cell dysfunction in microvasculature: relevance to disease processes. Clin Hemorheol Microcirc 2000;23:199-211. [PubMed: 11321441]

Park GY, Christman JW. Involvement of cyclooxygenase-2 and prostaglandins in the molecular pathogenesis of inflammatory lung diseases. Am J Physiol Lung Cell Mol Physiol 2006;290:L797805. [PubMed: 16603593]

Park YC, Lee CH, Kang HS, Chung HT, Kim HD. Wortmannin, a specific inhibitor of phosphatidylinositol-3-kinase, enhances LPS-induced NO production from murine peritoneal macrophages. Biochem Biophys Res Commun 1997;240:692-6. [PubMed: 9398628]

Penn PE, Jiang DZ, Fei RG, Sitnicka E, Wolf NS. Dissecting the hematopoietic microenvironment. IX. Further characterization of murine bone marrow stromal cells. Blood 1993;81:1205-13. [PubMed: 8443381]

Peters-Golden M, Canetti C, Mancuso P, Coffey MJ. Leukotrienes: underappreciated mediators of innate immune responses. J Immunol 2005;174:589-94. [PubMed: 15634873]

Pilaro AM, Laskin DL. Accumulation of activated mononuclear phagocytes in the liver following lipopolysaccharide treatment of rats. J Leukoc Biol 1986;40:29-41. [PubMed: 3011936]

Qureshi ST, Lariviere L, Leveque G, Clermont S, Moore KJ, Gros P, Malo D. Endotoxin-tolerant mice have mutations in Toll-like receptor 4 (Tlr4). J Exp Med 1999;189:615-25. [PubMed: 9989976]

Rabinowitz SS, Gordon S. Macrosialin, a macrophage-restricted membrane sialoprotein differentially glycosylated in response to inflammatory stimuli. J Exp Med 1991;174:827-36. [PubMed: 1919437]

Raetz CR, Whitfield C. Lipopolysaccharide endotoxins. Annu Rev Biochem 2002;71:635-700. [PubMed: 12045108]

Saklatvala J. The p38 MAP kinase pathway as a therapeutic target in inflammatory disease. Curr Opin Pharmacol 2004;4:372-7. [PubMed: 15251131]

Schabbauer G, Tencati M, Pedersen B, Pawlinski R, Mackman N. PI3K-Akt pathway suppresses coagulation and inflammation in endotoxemic mice. Arterioscler Thromb Vasc Biol 2004;24:19639. [PubMed: 15319270] 
Sleyster EC, Knook DL. Relation between localization and function of rat liver Kupffer cells. Lab Invest 1982;47:484-90. [PubMed: 6182391]

Su GL. Lipopolysaccharides in liver injury: molecular mechanisms of Kupffer cell activation. Am J Physiol Gastrointest Liver Physiol 2002;283:G256-65. [PubMed: 12121871]

Titos E, Claria J, Planaguma A, Lopez-Parra M, Gonzalez-Periz A, Gaya J, Miquel R, Arroyo V, Rodes J. Inhibition of 5-lipoxygenase-activating protein abrogates experimental liver injury: role of Kupffer cells. J Leukoc Biol 2005;78:871-8. [PubMed: 16033810]

Uematsu S, Matsumoto M, Takeda K, Akira S. Lipopolysaccharide-dependent prostaglandin E(2) production is regulated by the glutathione-dependent prostaglandin $\mathrm{E}(2)$ synthase gene induced by the Toll-like receptor 4/MyD88/NF-IL6 pathway. J Immunol 2002;168:5811-6. [PubMed: 12023384]

Van Bossuyt H, Wisse E. Structural changes produced in Kupffer cells in the rat liver by injection of lipopolysaccharide. Cell Tissue Res 1988;251:205-14. [PubMed: 3342439]

Vogel SN, Fenton M. Toll-like receptor 4 signalling: new perspectives on a complex signal-transduction problem. Biochem Soc Trans 2003;31:664-8. [PubMed: 12773178]

Vogel SN, Johnson D, Perera PY, Medvedev A, Lariviere L, Qureshi ST, Malo D. Cutting edge: functional characterization of the effect of the $\mathrm{C} 3 \mathrm{H} / \mathrm{HeJ}$ defect in mice that lack an Lpsn gene: in vivo evidence for a dominant negative mutation. J Immunol 1999;162:5666-70. [PubMed: 10229796]

Xiong Y, Hales DB. Expression, regulation, and production of tumor necrosis factor-alpha in mouse testicular interstitial macrophages in vitro. Endocrinology 1993;133:2568-73. [PubMed: 8243279] 

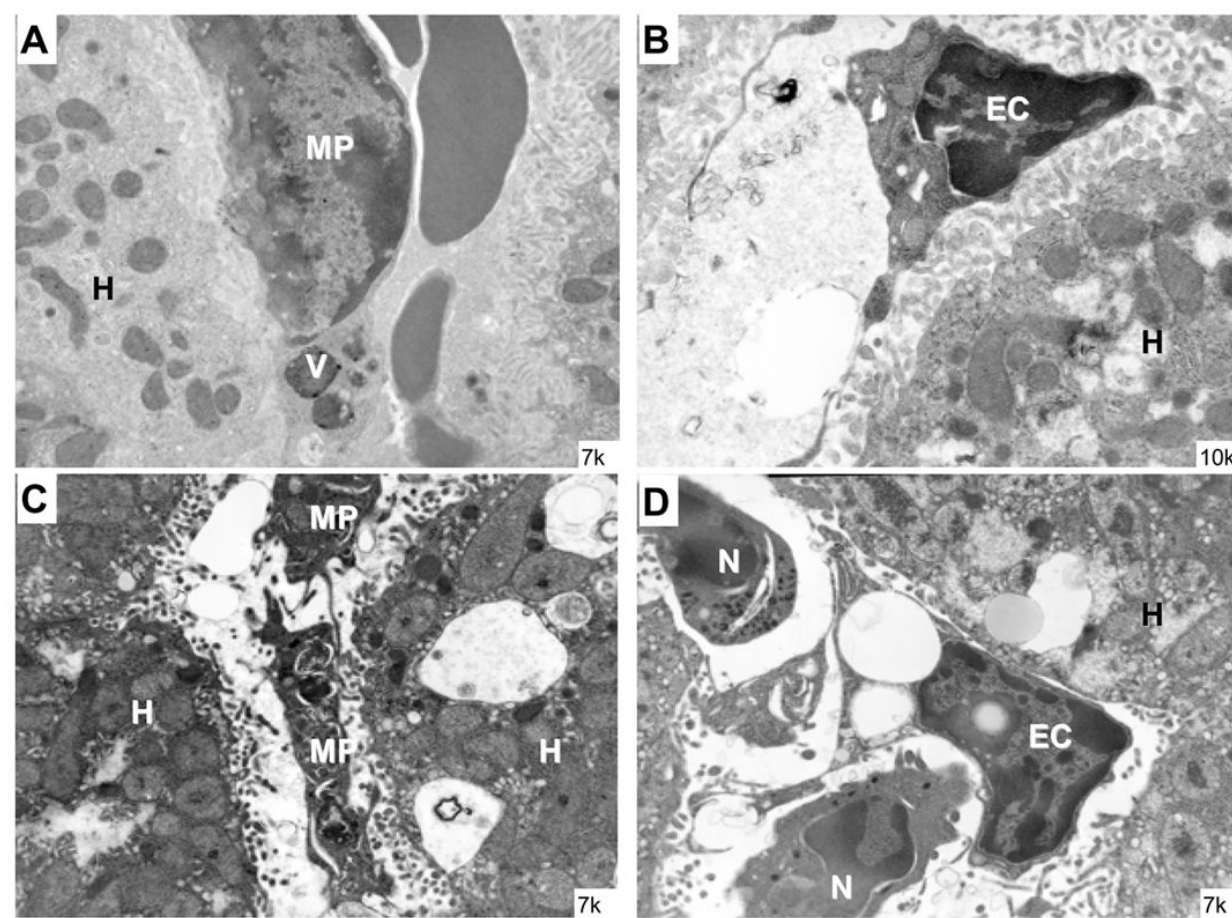

CTL

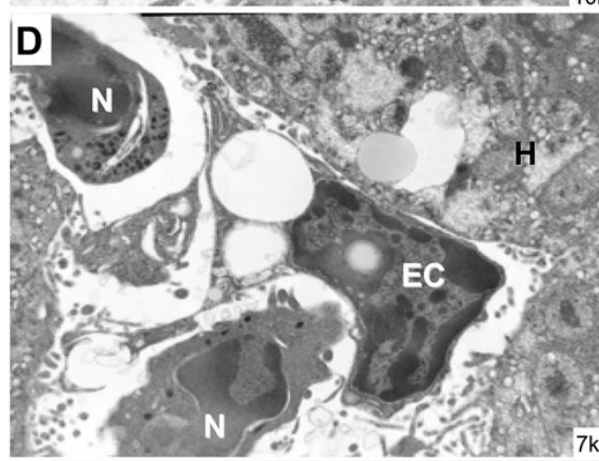

ETX

E

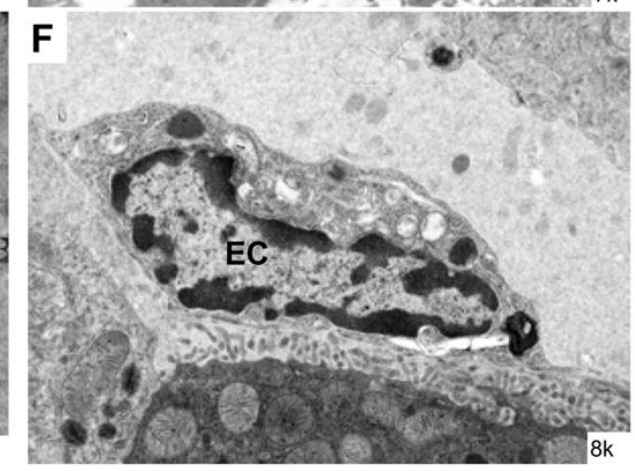

(3 hr)

ETX

(24 hr)

Figure 1.

Transmission electron microscopy of liver sinusoidal cells. Livers, collected $3 \mathrm{hr}$ and $24 \mathrm{hr}$ after treatment of $\mathrm{C} 3 \mathrm{H} / \mathrm{OuJ}$ mice with endotoxin (ETX) (panels C-F) or control (CTL) (panels A-B) were processed for electron microscopy as described in the Materials and Methods. Hepatocyte, H; macrophage, MP; endothelial cell, EC; vacuole, V; neutrophil, N. 


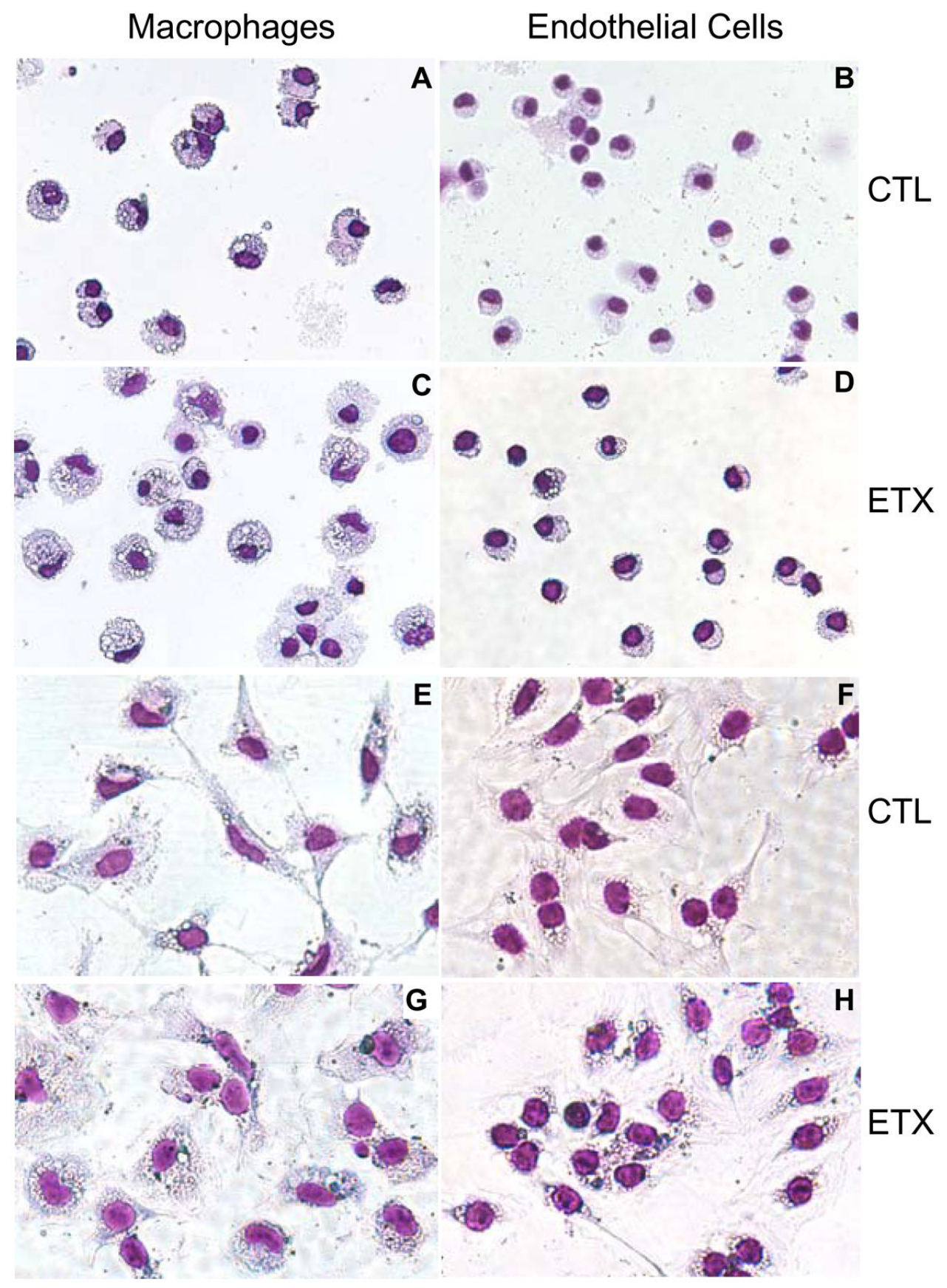

Figure 2.

Effects of ETX on liver macrophage and endothelial cell morphology. Cells, isolated from livers $24 \mathrm{hr}$ after treatment of $\mathrm{C} 3 \mathrm{H} / \mathrm{OuJ}$ mice with endotoxin (ETX) or control (CTL), were stained with Geimsa and photographed (40x magnification). Panels A-D: Cytospin preparations of cells were analyzed immediately after isolation. Panels $E-H$ : Cells were cultured ( $2.5 \times 10^{5} /$ well, 8-well slide chambers) in DMEM medium containing $10 \%$ FBS for $6 \mathrm{hr}$ prior to analysis. 

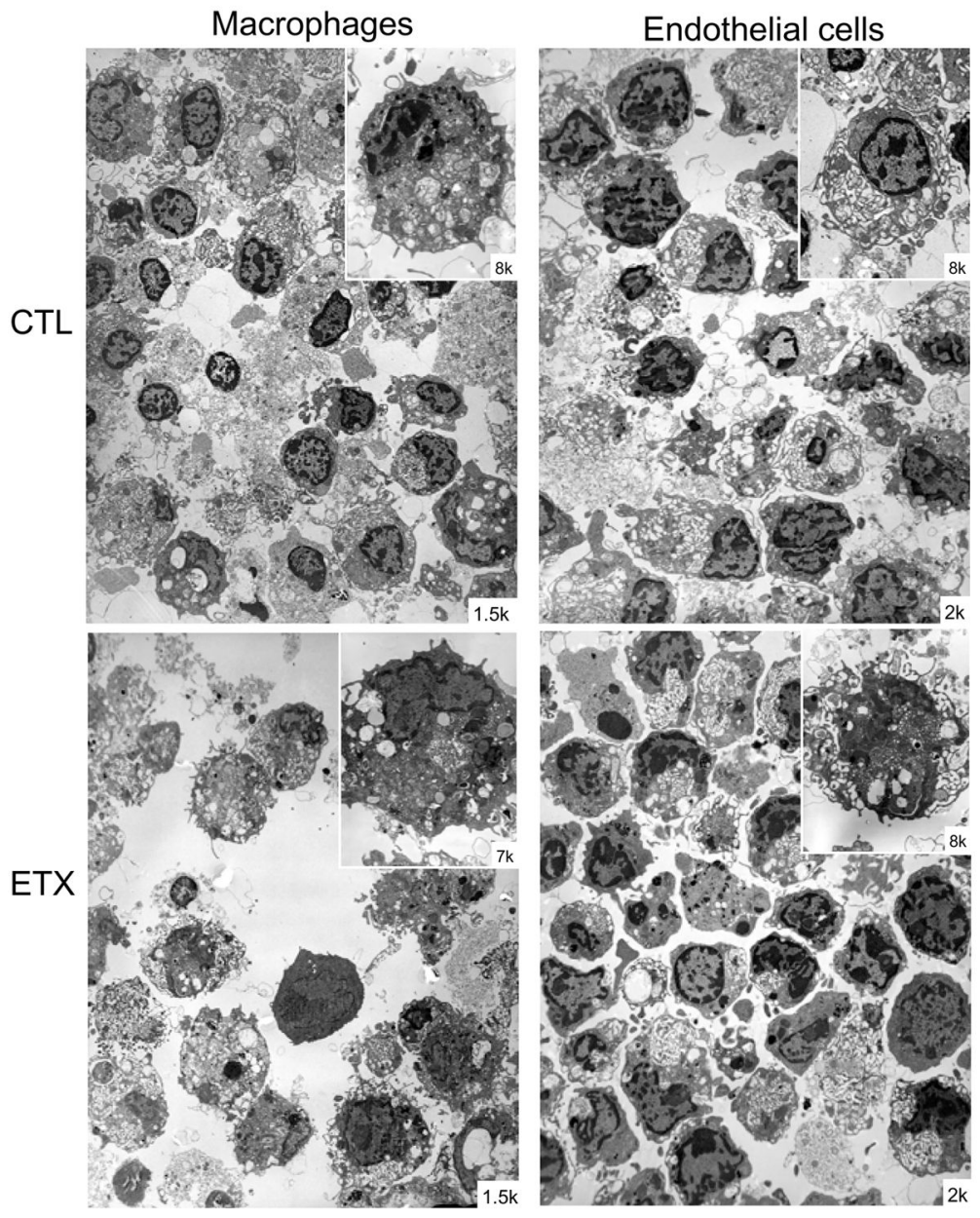

Figure 3.

Transmission electron microscopy of liver macrophages and endothelial cells. Cells, isolated $24 \mathrm{hr}$ after treatment of C3H/OuJ mice with ETX or CTL, were fixed with glutaraldehyde and processed for electron microscropy. Inset, representative enlarged macrophage or endothelial cell. 
OuJ
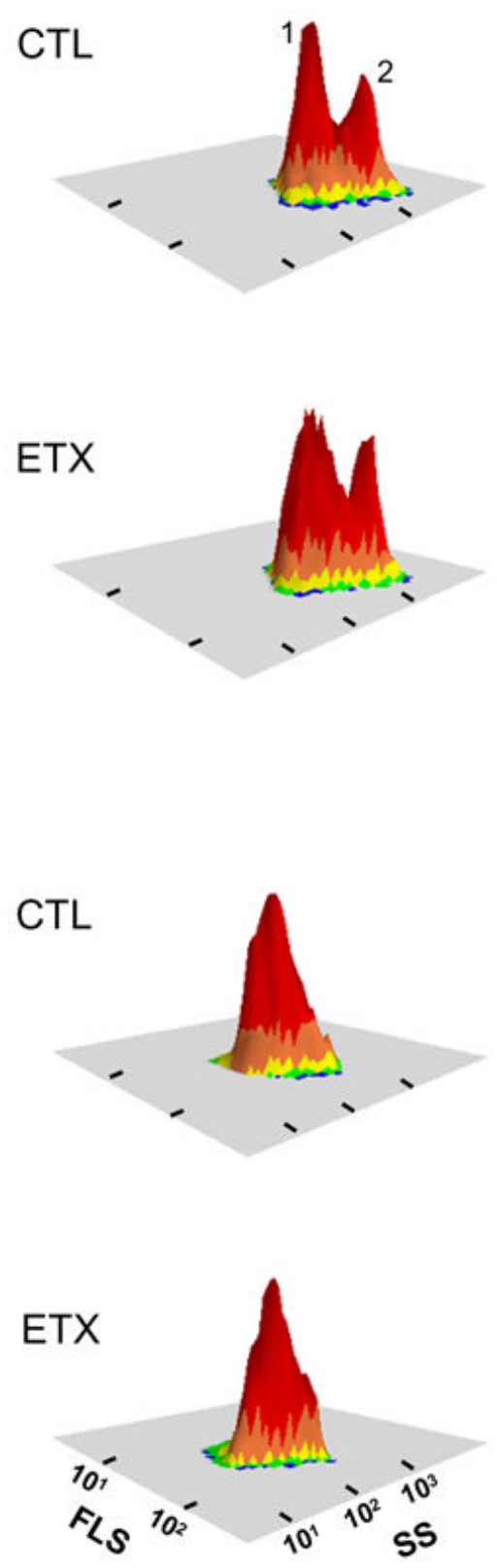

\section{HeJ}
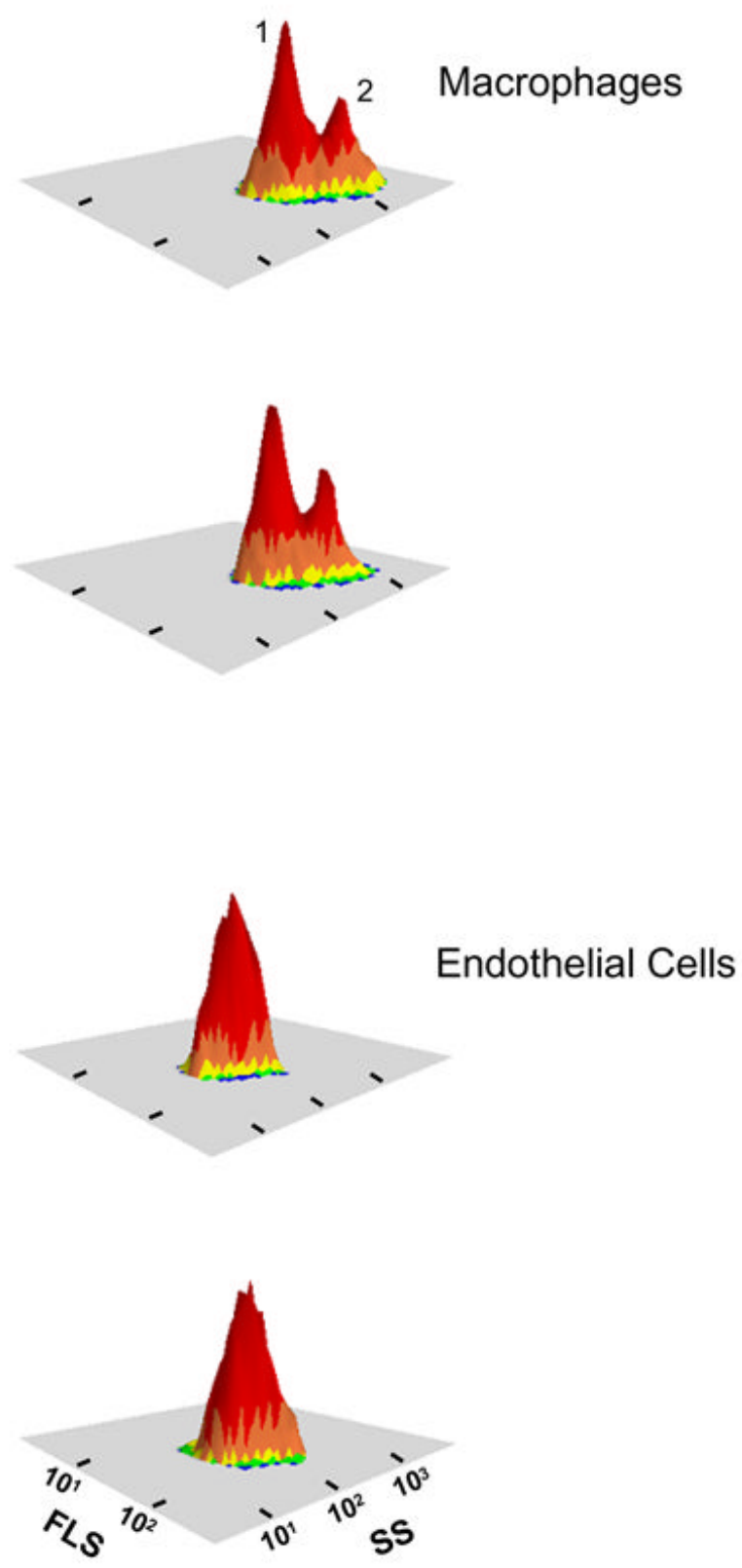

Figure 4.

Characterization of liver endothelial cells by flow cytometry. Cells, isolated from livers of $\mathrm{C} 3 \mathrm{H} / \mathrm{OuJ}$ or $\mathrm{C} 3 \mathrm{H} / \mathrm{HeJ}$ mice $48 \mathrm{hr}$ after administration of ETX or control (CTL), were analyzed by flow cytometry according to their light-scattering properties. One representative histogram for each time point from 4 separate experiments is shown. FLS, forward-angle light scatter; SS, side scatter. 


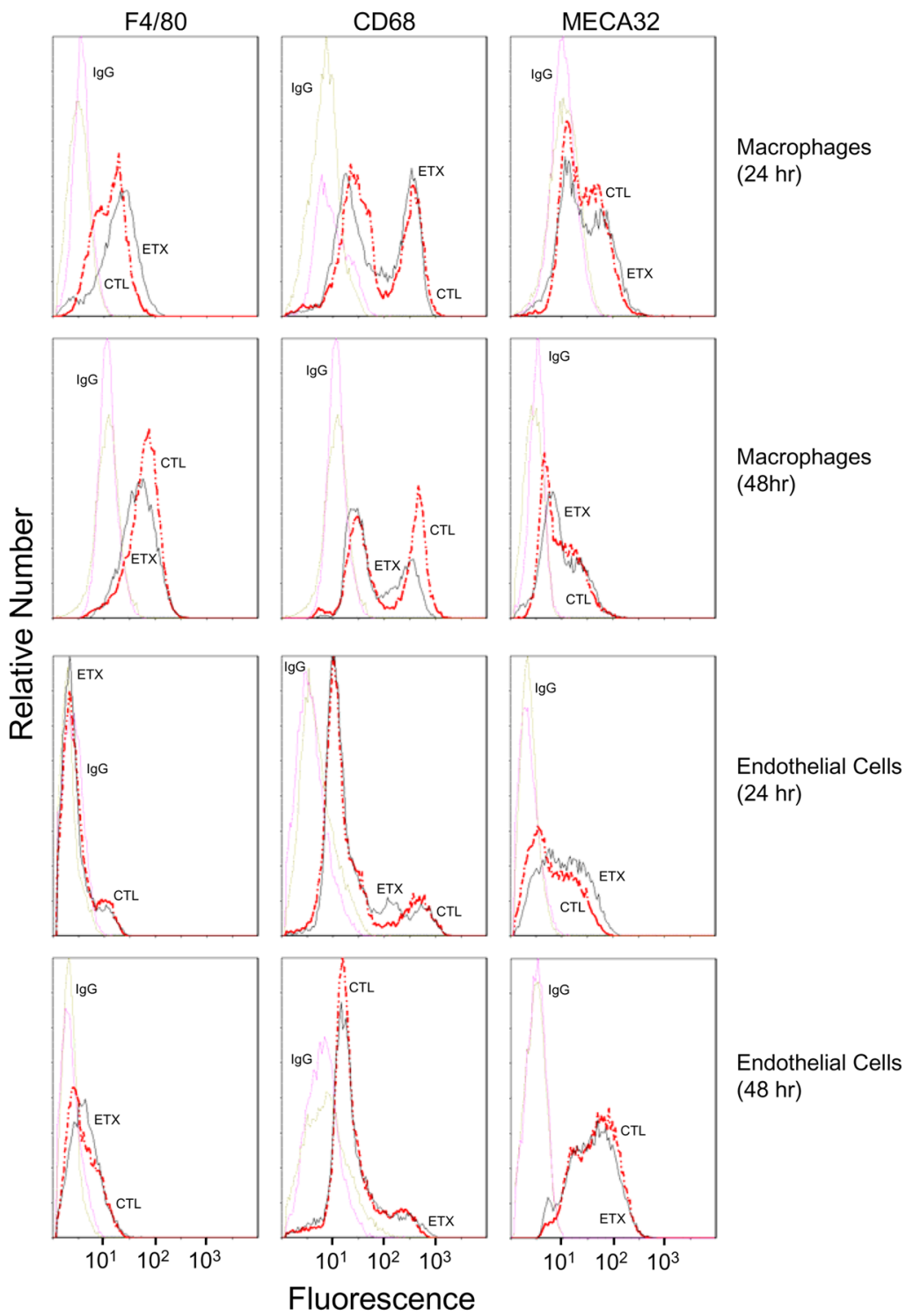

Figure 5.

Antigen expression by liver macrophages and endothelial cells from $\mathrm{C} 3 \mathrm{H} / \mathrm{OuJ}$ mice. Cells, isolated from livers of $\mathrm{C} 3 \mathrm{H} / \mathrm{OuJ}$ mice $24 \mathrm{hr}$ or $48 \mathrm{hr}$ after administration of ETX or control (CTL), were stained with antibodies to F4/80, CD68 or MECA32 or IgG control and then analyzed by flow cytometry. One representative from 2-3 separate experiments is shown. 


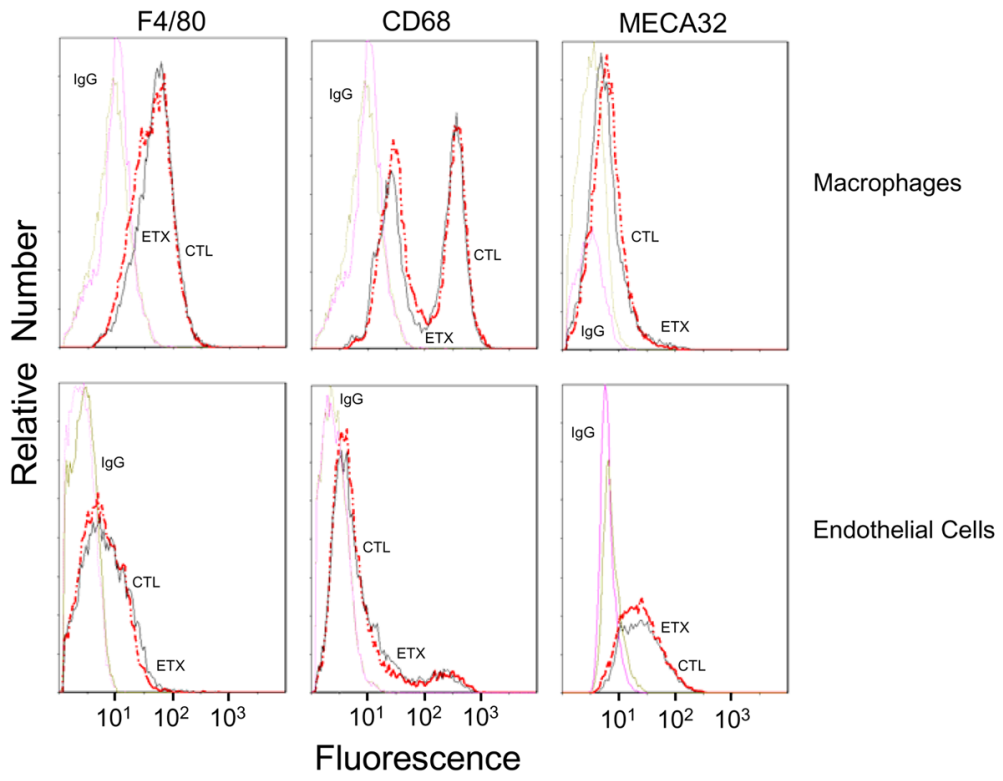

Figure 6.

Antigen expression by liver macrophages and endothelial cells from $\mathrm{C} 3 \mathrm{H} / \mathrm{HeJ}$ mice. Cells, isolated from livers of $\mathrm{C} 3 \mathrm{H} / \mathrm{HeJ}$ mice $48 \mathrm{hr}$ after administration of ETX or control (CTL), were stained with antibodies to F4/80, CD68 or MECA32 or IgG control and then analyzed by flow cytometry. One representative from 2-3 separate experiments is shown. 


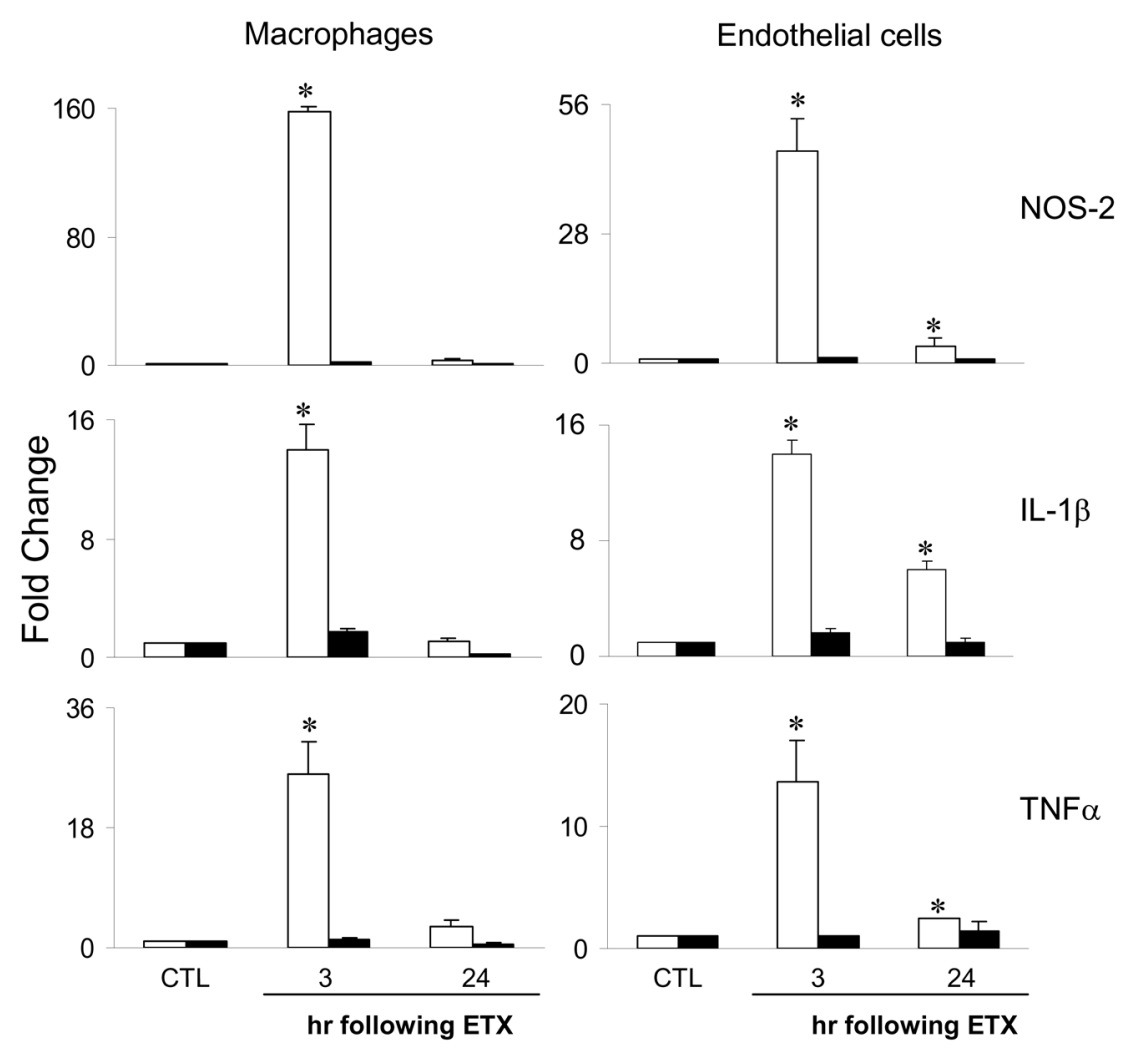

Figure 7.

Effects of acute endotoxemia on inflammatory gene expression. Macrophages and endothelial cells were isolated from livers of $\mathrm{C} 3 \mathrm{H} / \mathrm{OuJ}$ (white bars) or $\mathrm{C} 3 \mathrm{H} / \mathrm{HeJ}$ (black bars) mice 3 or 24 hr after administration of ETX or control (CTL). NOS-2, IL-1 $\beta$ and TNF $\alpha$ mRNA expression were quantified by real-time PCR. Data are presented as fold increase over CTL. Each bar is the mean $\pm \operatorname{SE}(\mathrm{n}=8-12)$ from 3 separate experiments. *Significantly different $(\mathrm{p}<0.05)$ from CTL. 


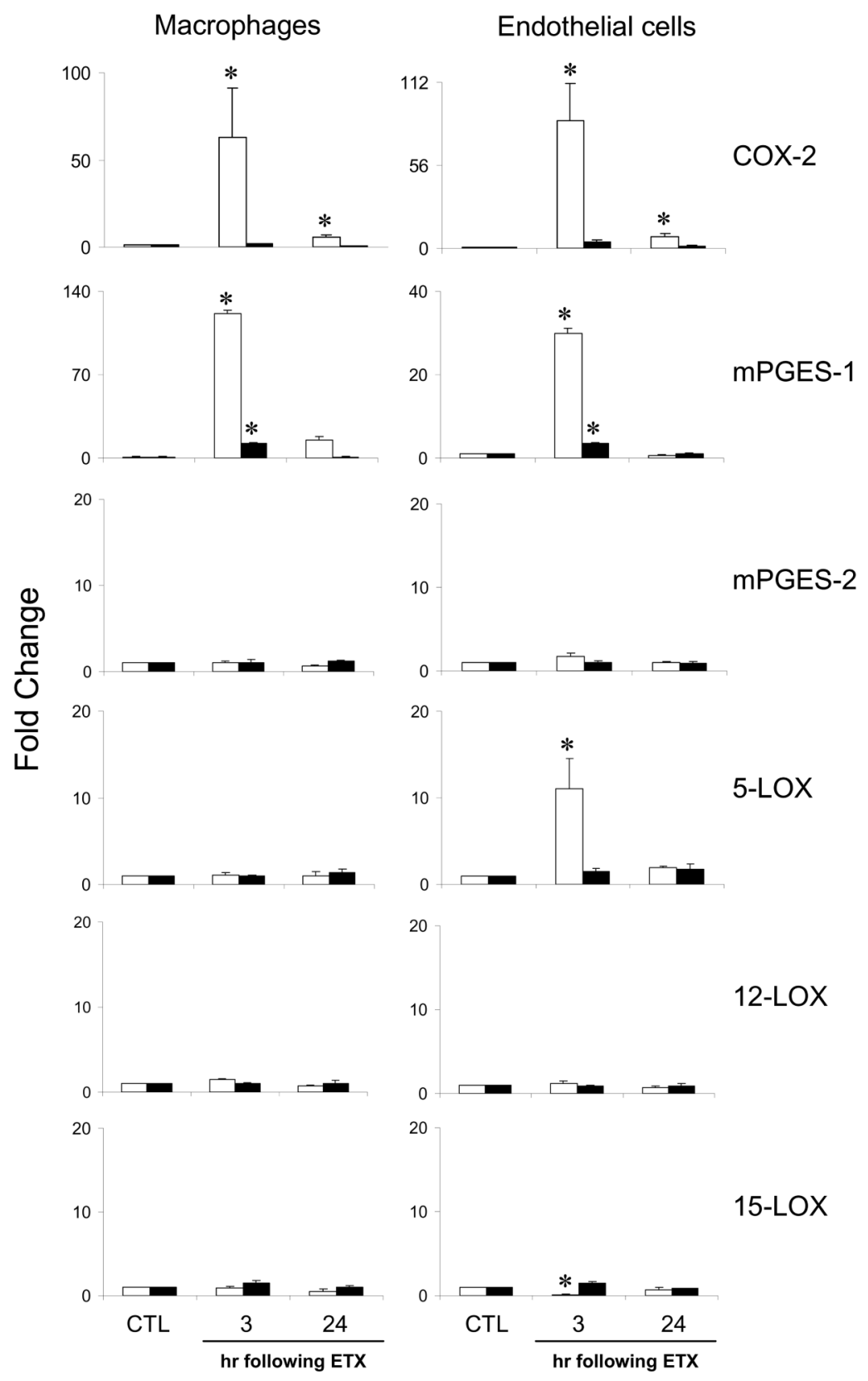

Figure 8.

Effects of acute endotoxemia on expression of genes involved in eicosanoid metabolism. Macrophages and endothelial cells were isolated from livers of $\mathrm{C} 3 \mathrm{H} / \mathrm{OuJ}$ (white bars) or $\mathrm{C} 3 \mathrm{H} /$ HeJ (black bars) mice 3 or $24 \mathrm{hr}$ after administration of ETX or control (CTL). mRNA expression for the indicated genes was quantified by real-time PCR. Data are presented as fold increase over CTL. Each bar is the mean $\pm \mathrm{SE}(\mathrm{n}=12)$ from 3 separate experiments. *Significantly different $(\mathrm{p}<0.05)$ from CTL. 


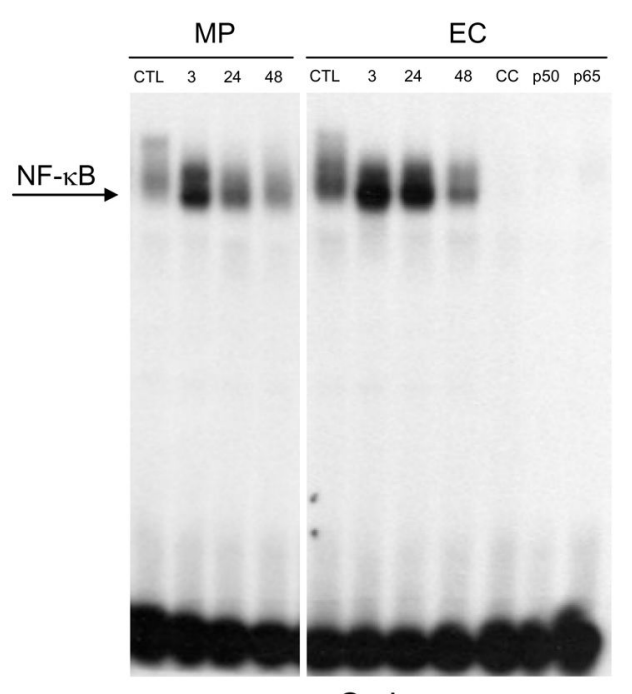

OuJ

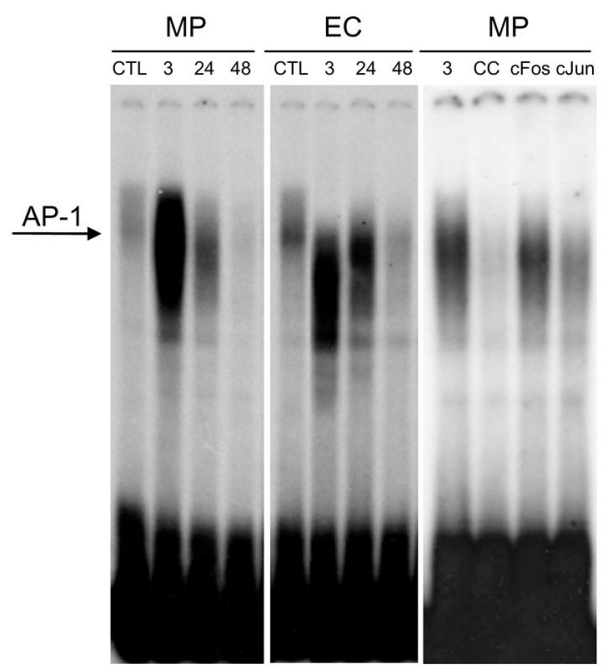

OuJ

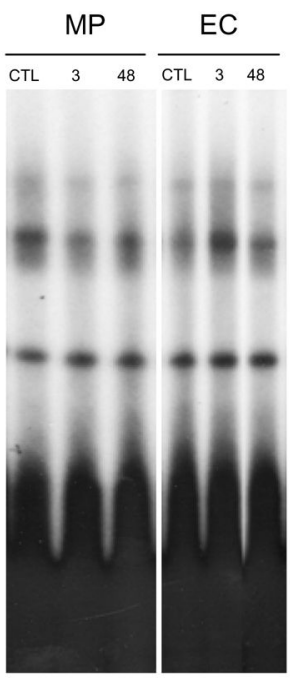

HeJ
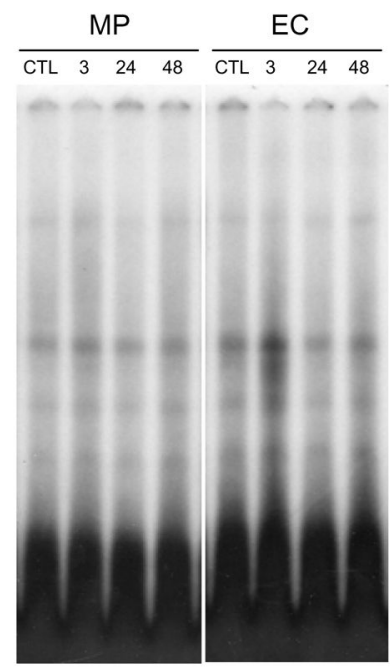

HeJ

Figure 9.

Effects of acute endotoxemia on NF- $\kappa \mathrm{B}$ and AP-1 nuclear binding activity. Macrophages (MP) and endothelial cells (EC) were isolated from livers of $\mathrm{C} 3 \mathrm{H} / \mathrm{OuJ}$ or $\mathrm{C} 3 \mathrm{H} / \mathrm{HeJ}$ mice 3-48 hr after administration of ETX or control (CTL). Upper panel, nuclear extracts were analyzed for $\mathrm{NF}-\kappa \mathrm{B}$ binding activity by EMSA. Endothelial cell extracts from $\mathrm{C} 3 \mathrm{H} / \mathrm{OuJ}$ mice isolated 48 $\mathrm{hr}$ after ETX administration were incubated at room temperature for $30 \mathrm{~min}$ with antibodies to NF- $\kappa \mathrm{B}$ p50, NF- $\kappa \mathrm{B}$ p65, or a 40-fold excess of unlabeled cold competitor (CC) prior to the labeled probe. One representative gel from three separate experiments is shown. Lower panel, nuclear extracts were analyzed for AP-1 binding activity by EMSA. Macrophage extracts from $\mathrm{C} 3 \mathrm{H} / \mathrm{OuJ}$ mice isolated $3 \mathrm{hr}$ after ETX administration were incubated at room temperature for $30 \mathrm{~min}$ with antibodies to $\mathrm{cFos}$, cJun, or a 40-fold excess of unlabeled cold competitor (CC) prior to the labeled probe. One representative gel from two separate experiments is shown. 

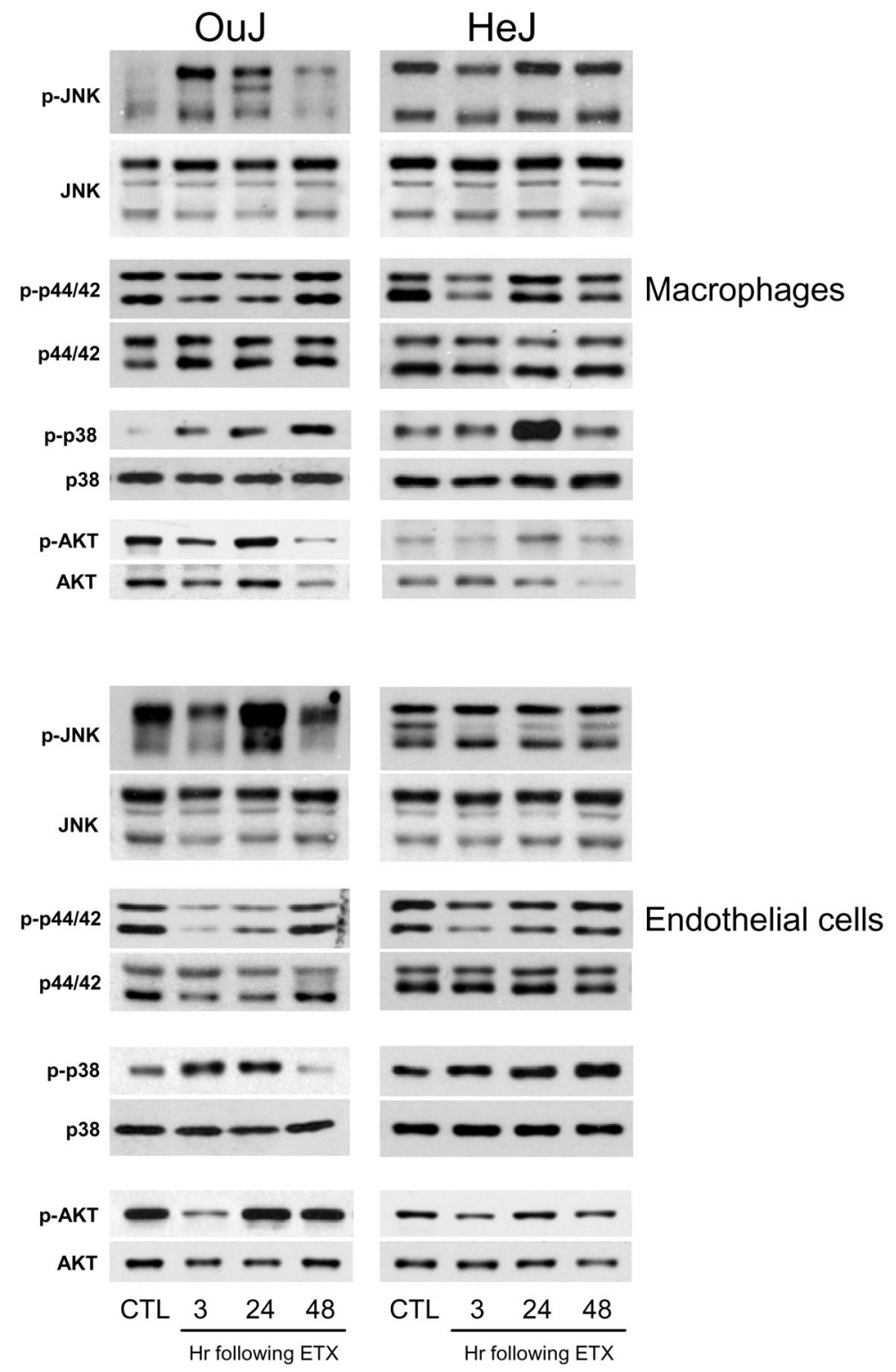

Figure 10.

Effects of acute endotoxemia on expression of cell signaling molecules. Macrophages and endothelial cells were isolated from livers of $\mathrm{C} 3 \mathrm{H} / \mathrm{OuJ}$ or $\mathrm{C} 3 \mathrm{H} / \mathrm{HeJ}$ mice 3-48 hr after administration of ETX or control (CTL). Cell lysates were prepared and analyzed by western blotting using antibodies to the total or phospho-JNK, p38 and p44/42 MAP kinase, and AKT. One representative gel from 3-4 separate experiments is shown. $10 \mu \mathrm{g}$ of cellular protein was loaded onto each lane of the gels. 
Table 1

Effects of acute endotoxemia on the number of macrophages and endothelial cells recovered from the liver

\begin{tabular}{lcccc}
\hline & & & Cells $\times \mathbf{1 0}$ / $/ \mathbf{m o u s e}$ \\
\hline & & CTL & ETX $(\mathbf{2 4} \mathbf{~ h r})$ & ETX (48 hr) \\
\hline Macrophages & OuJ & $1.6 \pm 0.1$ & $2.0 \pm 0.1$ & $2.9 \pm 0.4^{*}$ \\
& HeJ & $1.2 \pm 0.1$ & $1.3 \pm 0.1$ & $1.3 \pm 0.2$ \\
Endothelial Cells & OuJ & $4.5 \pm 0.4$ & $4.8 \pm 0.4$ & $5.3 \pm 0.9$ \\
& HeJ & $4.6 \pm 0.9$ & $4.5 \pm 0.3$ & $5.0 \pm 0.9$ \\
\hline
\end{tabular}

Cells were isolated $24 \mathrm{hr}$ or $48 \mathrm{hr}$ after treatment of mice with endotoxin (ETX) or control (CTL). Each value represents the mean \pm SEM from 3-18 separate experiments $(\mathrm{n}=11-72)$.

* Significantly $(\mathrm{p}<0.05)$ different from OuJ mice (ANOVA and $\mathrm{t}$-test). 